\title{
The Paxton Group of Southeastern New England
}

\section{U.S. GEOLOGICAL SURVEY BULLETIN 1814}

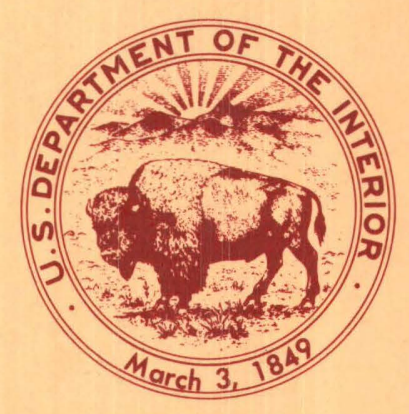




\section{SELECTED SERIES OF U.S. GEOLOGICAL SURVEY PUBLICATIONS}

\section{Periodicals}

Earthquakes \& Volcanoes (issued bimonthly).

Preliminary Determination of Epicenters (issued monthly).

\section{Technical Books and Reports}

Professional Papers are mainly comprehensive scientific reports of wide and lasting interest and importance to professional scientists and engineers. Included are reports on the results of resource studies and of topographic, hydrologic, and geologic investigations. They also include collections of related papers addressing different aspects of a single scientific topic.

Bulletins contain significant data and interpretations that are of lasting scientific interest but are generally more limited in scope or geographic coverage than Professional Papers. They include the results of resource studies and of geologic and topographic investigations; as well as collections of short papers related to a specific topic.

Water-Supply Papers are comprehensive reports that present significant interpretive results of hydrologic investigations of wide interest to professional geologists, hydrologists, and engineers. The series covers investigations in all phases of hydrology, including hydrogeology, availability of water, quality of water, and use of water.

Circulars present administrative information or important scientific information of wide popular interest in a format designed for distribution at no cost to the public. Information is usually of short-term interest.

Water-Resources Investigations Reports are papers of an interpretive nature made available to the public outside the formal USGS publications series. Copies are reprociuced on request unlike formal USGS publications, and they are also available for public inspection at depositories indicated in USGS catalogs.

Open-File Reports include unpublished manuscript reports, maps, and other material that are made available for public consultation at depositories. They are a nonpermanent form of publication that may be cited in other publications as sources of information.

\section{Maps}

Geologic Quadrangle Maps are multicolor geologic maps on topographic bases in 71/2- or 15 -minute quadrangle formats (scales mainly $1: 24,000$ or $1: 62,500$ ) showing bedrock, surficial, or engineering geology. Maps generally include brief texts; some maps include structure and columnar sections only.

Geophysical Investigations Maps are on topographic or planimetric bases at various scales; they show results of surveys using geophysical techniques, such as gravity, magnetic, seismic, or radioactivity, which reflect subsurface structures that are of economic or geologic significance. Many maps include correlations with the geology.

Miscellaneous Investigations Series Maps are on planimetric or topographic bases of regular and irregular areas at various scales; they present a wide variety of format and subject matter. The series also includes 71/2-minute quadrangle photogeologic maps on planimetric bases which show geology as interpreted from aerial photographs. Series also includes maps of Mars and the Moon.
Coal Investigations Maps are geologic maps on topographic or planimetric bases at various scales showing bedrock or surficial geology, stratigraphy, and structural relations in certain coal-resource areas.

Oil and Gas Investigations Charts show stratigraphic information for certain oil and gas fields and other areas having petroleum potential.

Miscellaneous Field Studies Maps are multicolor or black-andwhite maps on topographic or planimetric bases on quadrangle or irregular areas at various scales. Pre-1971 maps show bedrock geology in relation to specific mining or mineral-deposit problems; post-1971 maps are primarily black-and-white maps on various subjects such as environmental studies or wilderness mineral investigations.

Hydrologic Investigations Atlases are multicolored or black-andwhite maps on topographic or planimetric bases presenting a wide range of geohydrologic data of both regular and irregular areas; principal scale is $1: 24,000$ and regional studies are at $1: 250,000$ scale or smaller.

\section{Catalogs}

Permanent catalogs, as well as some others, giving comprehensive listings of U.S. Geological Survey publications are available under the conditions indicated below from the U.S. Geological Survey, Books and Open-File Reports Section, Federal Center, Box 25425, Denver, CO 80225. (See latest Price and Availability List.)

"Publications of the Geological Survey, 1879-1961" may be purchased by mail and over the counter in paperback book form and as a set of microfiche.

"Publications of the Geological Survey, 1962-1970" may be purchased by mail and over the counter in paperback book form and as a set of microfiche.

"Publications of the U.S. Geological Survey, 1971- 1981" may be purchased by mail and over the counter in paperback book form (two volumes, publications listing and index) and as a set of microfiche.

Supplements for 1982, 1983, 1984, 1985, 1986, and for subsequent years since the last permanent catalog may be purchased by mail and over the counter in paperback book form.

State catalogs, "List of U.S. Geological Survey Geologic and Water-Supply Reports and Maps For (State)," may be purchased by mail and over the counter in paperback booklet form only.

"Price and Availability List of U.S. Geological Survey Publications," issued annually, is available free of charge in paperback booklet form only.

Selected copies of a monthly catalog "New Publications of the U.S. Geological Survey" available free of charge by mail or may be obtained over the counter in paperback booklet form only. Those wishing a free subscription to the monthly catalog "New Publications of the U.S. Geological Survey" should write to the U.S. Geological Survey, 582 National Center, Reston, VA 22092.

Note.--Prices of Government publications listed in older catalogs, announcements, and publications may be incorrect. Therefore, the prices charged may differ from the prices in catalogs, announcements, and publications. 


\section{The Paxton Group of Southeastern New England}

\section{By PATRICK J. BAROSH and GEORGE E. MOORE, JR.}

The Paxton Schist is herein elevated to group status. The upper part of the former Paxton Schist is now called the Southbridge Formation, and the lower part of the former Paxton Schist is now called the Dudley Formation 
DEPARTMENT OF THE INTERIOR

DONALD PAUL HODEL, Secretary

\section{U.S. GEOLOGICAL SURVEY}

Dallas L. Peck, Director

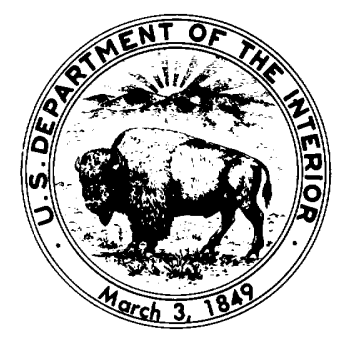

Any use of trade names in this publication is for descriptive purposes only and does not imply endorsement by the U.S. Geological Survey

For sale by the Books and Open-File Reports Section, U.S. Geological Survey, Federal Center, Box 25425, Denver, CO 80225

\section{Library of Congress Cataloging in Publication Data}

Barosh, Patrick J.

The Paxton Group of southeastern New England.

(U.S. Geological Survey bulletin ; 1814)

Bibliography: $p$.

Supt. of Docs. no. : | 19.3:1814

1. Geology, Stratigraphic-Pre-Ordovician. 2. Geology-New England.

3. Paxton Group. I. Moore, George E. II. Title. III. Series.

QE75.B9 no. 1814 557.3 s [551.7'31'0974] 87-19569

[QE660] 


\title{
CONTENTS
}

\author{
Abstract 1 \\ Introduction 1 \\ Acknowledgments 1
}

History of stratigraphic nomenclature 1

Revised stratigraphic nomenclature 4

Characteristic lithologies of the Paxton Group 4

Dudley Formation 6

Southbridge Formation 7

Paxton Group undivided 9

Geomorphic expression 9

Age 9

Correlation 10

Original lithology and environment of deposition $\mathbf{1 0}$

References 11

Appendix: Measured stratigraphic sections of the Paxton Group 13

\section{FIGURES}

1. Index map of southeast New England showing location of the $7 \frac{1}{2}-$ minute quadrangles involved with the type section of the Paxton Group and their regional geologic setting 2

2. Diagram showing history of the stratigraphic nomenclature of the Paxton Group in the Worcester area, Massachusetts, and adjacent Connecticut 3

3. Map of parts of the Webster and Southbridge Quadrangles, Massachusetts, showing location of type sections of the Dudley and Southbridge Formations (reference section for the Paxton Group) 5

4. Columnar section showing the Paxton Group and bordering stratigraphic units 6

5. Diagram showing regional correlation of the Paxton Group 7

\section{TABLE}

1. Mineralogic composition of rock samples from the Southbridge Formation 


\title{
The Paxton Group of Southeastern New England
}

\author{
By Patrick J. Barosh and George E. Moore, Jr.
}

\section{Abstract}

The Paxton Schist of Perry and Emerson (1903), referred to as the "Paxton Quartz Schist" by Emerson (1917), consists of medium-gray, thin- to medium-bedded, fine- to coarse-grained schistose granulite, which weathers the same color or slightly darker with a brownish cast. It is preOrdovician and probably late Proterozoic in age. The Paxton is herein elevated to group status. The Paxton as revised excludes strata now assigned to the overlying Brimfield Group (Peper and others, 1975). The lower, fine-grained part of the Paxton is herein named the Dudley Formation, and the upper, interbedded, fine- to coarse-grained part is referred to as the Southbridge Formation (Pease, 1972). An excellent reference section for the Paxton is present along the northeast side of the Quinebaug River southeast of Southbridge, Mass. The approximate thickness of exposed mapped width of the Paxton is 4,700 meters ( $\mathrm{m}$ ), of which the Dudley forms $1,000 \mathrm{~m}$ and the Southbridge $3,700 \mathrm{~m}$.

The Paxton conformably overlies the Oakdale Formation and underlies the Brimfield Group in its type area in central Massachusetts. It forms a northeast-trending belt extending from east-central Connecticut into southern Maine and probably into the central Maine coast. It is correlative with the Hebron Formation in eastern Connecticut, the upper part of the Berwick Formation in southern Maine, and the Rye Formation on the New Hampshire coast.

A slight coarsening of the unit toward the northwest suggests a source in that direction.

\section{INTRODUCTION}

A series of stratigraphic studies was conducted in northeastern Connecticut and adjacent Massachusetts (fig. 1) both to aid in quadrangle mapping and to gain a better understanding of the regional stratigraphy and structure. The informally named "Paxton Group" (Barosh, 1976, 1977) is one of the units that has been studied extensively, and various stages of its investigation are reported on in several abstracts, open-file reports, and guidebook articles. This report presents a summary of this work and a formal definition of stratigraphic terms. The Paxton is herein formally revised and raised

Manuscript approved for publication, July 22, 1987. to group status. The Paxton Group, as revised, includes the Dudley Formation, which is herein proposed for strata previously informally referred to as the "lower Paxton" by Barosh (1976) and Pease and Barosh (1981), and the Southbridge Formation of Pease (1972).

The recognition of the Paxton Group and its divisions provides important structural control in an area of similar lithologies. The study of this group also has been instrumental in establishing the proper stratigraphic sequence in the region and a better understanding of its geologic history. The Paxton has been followed southwestward to its terminus in east-central Connecticut and northeastward across New Hampshire into southern Maine, and thus plays a key role in integrating the geology across this region.

\section{Acknowledgments}

This work was supported mainly by the U.S. Geological Survey in cooperation with the States of Connecticut and Massachusetts, and in part by the U.S. Nuclear Regulatory Commission. Carl K. Johnson assisted in measuring some stratigraphic sections. The aid of M.H. Pease, Jr., throughout this study is gratefully appreciated.

\section{HISTORY OF STRATIGRAPHIC NOMENCLATURE}

The Paxton Schist was first described by Perry and Emerson (1903) in their study of the Worcester, Mass., area, although it was mentioned earlier by Emerson (1898), who referred to it as the "Paxton Whetstone Schist." They described the Paxton as quartzose mica schist, of brownish-gray color and frequently containing alternating lighter bands of greenish color, lying between the Oakdale Quartzite on the east and the Brimfield Schist on the west. These three units, the Oakdale, Paxton, Brimfield, form a gently to moderately west dipping conformable sequence in the Worcester region. The unit was described from a type area west of Worcester in the western part of the Worcester North and Worcester South $712^{\prime \prime}$ quadrangles, and the name was taken from Paxton, a town that lies a little farther west 


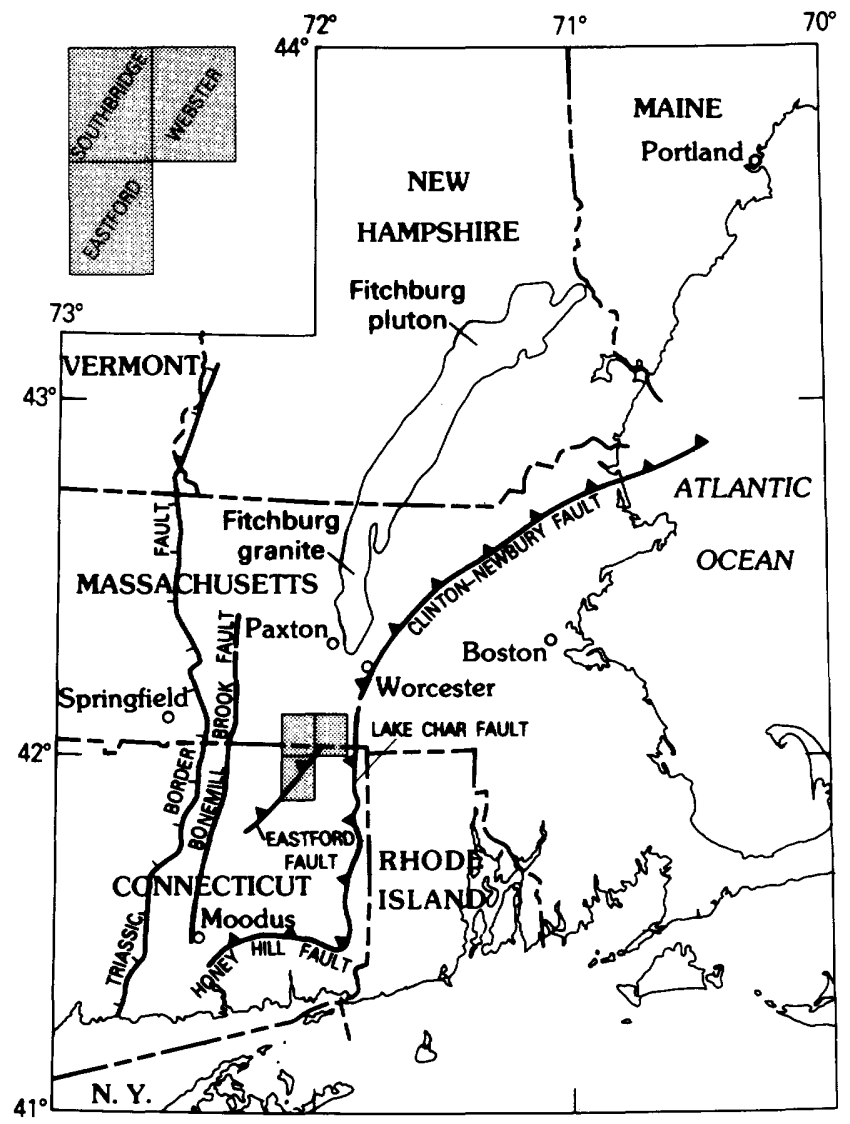

\begin{tabular}{llllll}
0 & 10 & 20 & 30 & 40 & 50 \\
\hline
\end{tabular}

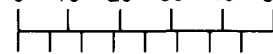

010203040506070 KILOMETERS

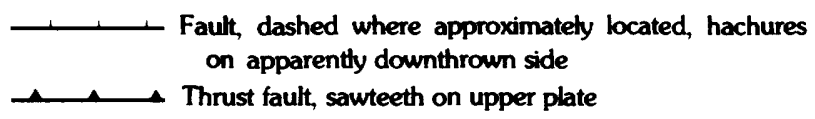

Figure 1. Index map of southeast New England showing location of the 71/2-minute quadrangles involved with the type section of the Paxton Group and their regional geologic setting.

(fig. 1). No type section was given. Strata in this area are typical of the Paxton, but are not well exposed. Emerson, who in 1917 referred to the unit as the "Paxton Quartz Schist," also shows belts of Paxton within the eastern part of the Brimfield. Emerson (1917, p. 62) stated that "the Paxton passes in pitching folds beneath the Brimfield" in this area. In addition, he considered the possibility that the Paxton and overlying Brimfield might be higher metamorphic grade equivalents of the Oakdale and a unit to the east, the Worcester Phyllite, respectively, thus creating a structural symmetry with matching units on either side of the valley near Worcester (fig. 2). Emerson (1917) shows the Brimfield, Paxton, and Oakdale strata extending southward to the Connecticut border. The Brimfield Schist was recognized in Connecticut, but strata equivalent to the Paxton and Oakdale were not divided and were mapped as the Hebron Gneiss by
Gregory and Robinson (1907). Gregory and Robinson (1907) locally separated a micaceous schist interval within the Hebron.

The bedrock geology of much of this sequence in eastern Connecticut was mapped during the period $1955-68$, at a scale of $1: 24,000$, by the U.S. Geological Survey.

As a result of this work, which was summarized by H.R. Dixon and L.W. Lundgren, Jr. (1968), the muscovitic schist interval of Gregory and Robinson (1907) was separated as a new formation, the Scotland Schist. Dixon and Lundgren hypothesized the Scotland Schist to lie along the center of a recumbent isoclinical syncline, the axis of which traced a sinuous path across eastern Connecticut. Rocks of the Hebron Formation were mapped structurally above and below the Scotland; those above were considered to be on the overturned limb of the syncline. The Brimfield Schist, which lies structurally above the Hebron, was also considered to be overturned. Dixon and Lundgren thus essentially reversed the order of the stratigraphy, placing the Scotland Schist at the top, the Hebron Formation in the middle, and the Brimfield Schist at the base. This interpretation, which has been followed by Rodgers (1985) on the geologic map of Connecticut, is incompatible with the information set forth in this report.

From 1966 to 1975 a program of detailed geologic quadrangle mapping under the direction of M.H. Pease, Jr., was undertaken in the type area of the Brimfield Schist of Connecticut and Massachusetts. This work resulted in revision of the Hebron Formation and Brimfield Schist and in recognition that the stratigraphic section is not overturned, as interpreted by Dixon and Lundgren, but is in a right-side-up homoclinical sequence. It also demonstrated that the "folds" of Paxton in the Brimfield of Emerson (1917) are intervals of amphibolite and pyroxene-bearing biotite schist and gneiss within the Brimfield and not part of the Paxton. The Brimfield was elevated to group status and subdivided, from base upward, into the Bigelow Brook, Hamilton Reservoir, and Mount Pisgah Formations (Pease, 1972; Peper and Pease, 1975, 1976; Peper and others, 1975).

The first quadrangle mapped under this program was the Eastford Quadrangle (Pease, 1972). The Hebron Formation was divided into two formations separated by the northeast-trending Eastford fault. The strata northwest of the fault were found to underlie and be older than the Brimfield; they were formally named the Southbridge Formation, for extensive exposures in the town of Southbridge, Mass., immediately on strike to the north of the Eastford Quadrangle. These strata, which have been mapped by G.E. Moore, Jr. (1978), are equivalent to the upper part of the Paxton of Emerson (1917). Pease recognized that the Brimfield overlying the Southbridge is younger and in right-side-up sequence. The Hebron 


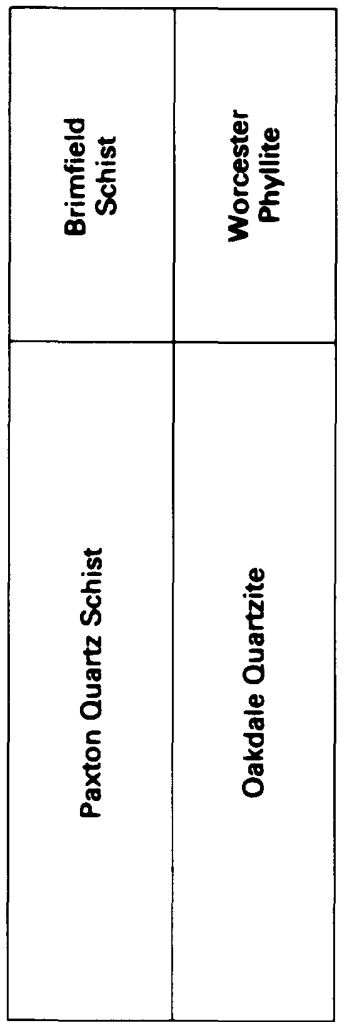

EASTFORD QUAD.

Pease (1972)

WEBSTER QUAD. Barosh (1974)

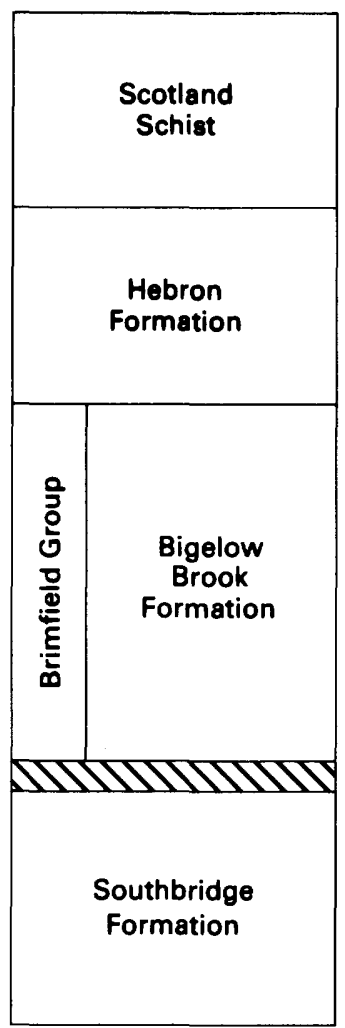

WORCESTER AREA Barosh (1976, 1977)
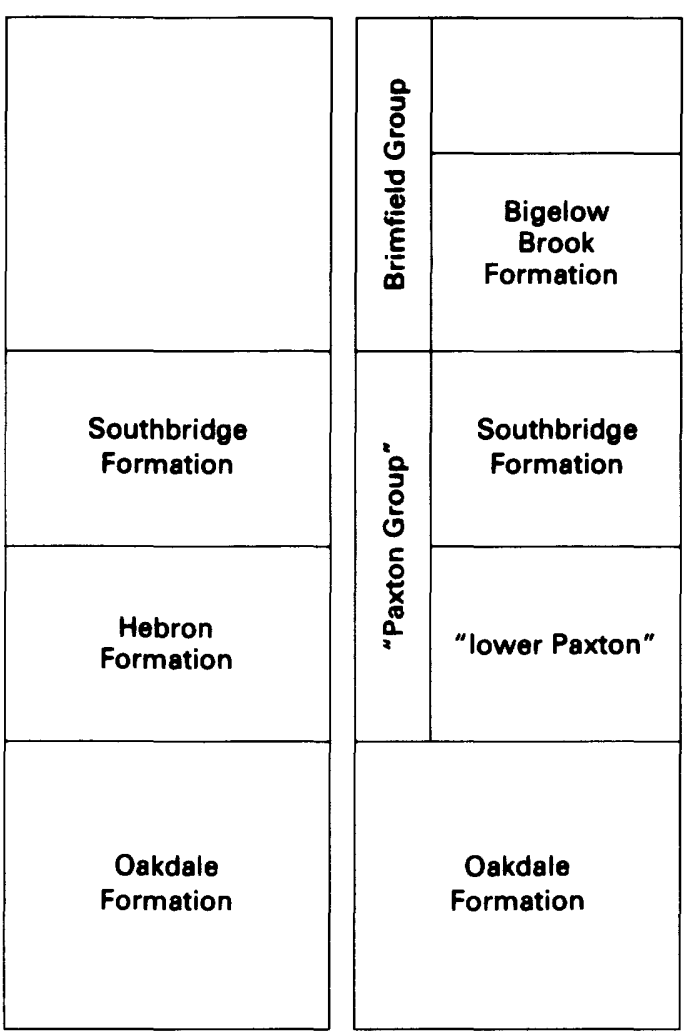

WORCESTER AREA This report

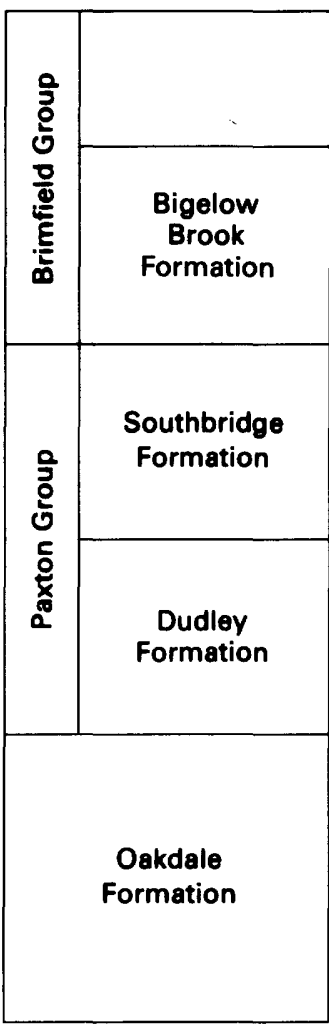

Figure 2. History of the stratigraphic nomenclature of the Paxton Group in the Worcester area, Massachusetts, and adjacent Connecticut. Not a correlation chart.

Formation and Scotland Schist were restricted to the southeast side of the fault. For lack of evidence to the contrary at the time of publication of the geologic map of the Eastford Quadrangle, Pease accepted the stratigraphic sequence of Dixon and Lundgren (1968) for the strata east of the fault and placed them as younger than the Brimfield (fig. 2).

A study of the Oakdale and Paxton strata in adjacent Massachusetts was started in the early 1970's when a program of geologic mapping under the direction of P.J. Barosh, then with the U.S. Geological Survey, was undertaken in the region from north of Worcester into the northeast corner of Connecticut. The division of the Hebron into Southbridge and Hebron made by Pease (1972) was recognized in the Webster Quadrangle as a stratigraphic division, even where the Eastford fault is absent (Barosh, 1974). The reduced Hebron of Pease (1972) was found to be older than the overlying Southbridge (Barosh, 1974, 1976, 1977, 1984; Barosh and others, 1977). The Oakdale of Emerson (1917) was found to lie stratigraphically beneath Pease's Hebron and to extend into Connecticut, where it is stratigraphically the eastern part of the Hebron (Barosh, 1974) (fig. 2). Again, this west-dipping sequence is shown to be right- side-up, and not on the overturned limb of a recumbent syncline as interpreted by Dixon and Lundgren (1968).

Because both the Paxton and Oakdale strata are well represented at the type areas, the names were retained. The Paxton Quartz Schist was informally revised as the "Paxton Group" (Barosh, 1976, 1977); the term "Southbridge Formation" was retained for the upper part of the Paxton Group, and the underlying strata were informally designated "lower Paxton" (Barosh, 1976, 1977) (fig. 2). The name "Oakdale Quartzite" was changed to "Oakdale Formation" because it is mostly metasiltstone, with little or no true quartzite (Barosh, 1974, 1977; Peck, 1975). Grew (1970) also used the term "Oakdale Formation," but included additional strata under that term.

Subsequent geologic mapping in eastern Connecticut has shown that the Scotland Schist is a member within the Oakdale (Barosh and Pease, 1981; Pease and Barosh, 1981). Such muscovite schist lenses are characteristic of the Oakdale and are found in its type area. A definitive report by Pease (in press) correlates the Oakdale Formation and Paxton Group with strata in northeast Connecticut and formally redefines the Hebron and Scotland stratigraphic units. 
REVISED STRATIGRAPHIC NOMENCLATURE

This report formally elevates the Paxton to group status and introduces the name "Dudley Formation" for the strata of the Paxton Group that lie beneath the Southbridge Formation (fig. 2). The type area of the Southbridge Formation assigned by Pease (1972) to "nearly continuous exposures in the hills north of the Quinebaug River and east of the town of Southbridge" is herein expanded. The type section was designated by Pease (1972) to extend from Cady Brook in the Southbridge Quandrangle southeast to the quadrangle border and did not include the lower part of the formation. The type section is herein extended southeastward into the Webster Quadrangle along the northeast side of the Quinebaug River to the top of the Dudley Formation at a railroad bed crossing of a stream tributary to the Quinebaug about 1 kilometer $(\mathrm{km})$ southeast of the highway bridge over the river in West Dudley (see appendix for specific location) (fig. 3). The Dudley Formation is named for the town of Dudley, Mass. The type section, which lies entirely within the town of Dudley, adjoins the Southbridge section at the railroad bed crossing and extends southeast along the northeast side of the Quinebaug River to a small pond southeast of Mill Road (see appendix for specific location) (fig. 3).

The Dudley and Southbridge have thus far been separated by mapping only in southern Massachusetts and northeastern Connecticut. Farther north in Massachusetts and New Hampshire, these strata are mapped as Paxton Group undivided.

Thin units of similar strata shown by Emerson (1917) as Paxton farther west, between bands of Brimfield, are shown by Peper and others (1975) to be stratigraphic components of the Brimfield Group and are excluded from the Paxton.

\section{CHARACTERISTIC LITHOLOGIES OF THE PAXTON GROUP}

The Paxton Group is a sequence of metagraywacke strata lying above metasiltstone strata of the Oakdale and below the first significant sillimanite schist unit of an alternating schist and gneiss sequence of the Bigelow Brook Formation at the base of the Brimfield Group (fig. 4). Both contacts are conformable.

The Paxton Group consists mostly of thin- to medium-bedded, fine- to coarse-grained graywacke that has undergone moderate to high-grade regional metamorphism. The beds have a schistose to granulose texture and are composed chiefly of quartz, feldspar, and biotite, which gives them a salt and pepper appearance. Calc-silicate-bearing beds occur at many horizons throughout the section and form lighter colored bands with a greenish tint. The general composition of the Paxton is similar to that of the metasiltstone of the Oakdale Formation, but the Paxton is coarser grained (almost entirely in the sand size range) and lacks the silicic siltstone and thick muscovite schist interbeds that are found in the Oakdale. Pegmatite bodies are common in the Paxton and commonly constitute 15 percent of the section and locally up to 25 percent. The overlying Brimfield is a more heterogeneous unit containing rustyweathering schist interbedded with various types of gneissic rock (fig. 5).

Various metamorphic terms ranging from schist to gneiss have been used to designate the metamorphosed graywacke that is most characteristic of the Paxton Group strata, but most of the conventional terms do not appear to adequately distinguish the diagnostic rock type of the Paxton Group from strata above and below. Very little of the rock is actually schist, although weathering locally causes a flaking and splitting of the rock along bedding planes that mimics schistosity. Gneiss is even less common, although thin bedding and sedimentary lamination in these strata locally appear to be accentuated by metamorphic processes to produce a gneissoid appearance. Grains within individual beds are generally equigranular, and the scattered mica flakes that produce a salt and pepper appearance are not generally parallel to bedding except near boundaries with shaly partings. The term "schistose granulite" is considered most suitable for the metagraywacke that makes up most of this group and is used in the following descriptions.

The schistose granulite is medium to dark gray and weathers the same color or slightly darker with a brownish cast. It is an equigranular rock with a granular to slightly schistose texture. It is composed of 30 to 50 percent quartz, 25 to 50 percent plagioclase, and 10 to 20 percent biotite (table 1, samples 1-5). Medium- to darkgreen grains of diopside and actinolite-hornblende, generally less than 1 millimeter $(\mathrm{mm})$ in length, are minor constituents (table 1 , samples 2,3 ). They occur most commonly in the middle and upper parts of the Southbridge. The biotite, as seen in thin section, tends to be brownish red in rock containing iron-rich amphibole and pyroxene and olive brown elsewhere. It is the biotite that imparts a brownish cast to the weathered rock. Layers having a high biotite content are dark gray where fresh and relatively coarse grained. The plagioclase is mostly intermediate plagioclase but is very calcic where associated with other calc-silicate-bearing minerals. Locally, chlorite and muscovite are present (table 1, samples 1, 2 , 5 ). The more schistose strata contain garnet, generally amounting to less than 1 percent and less than 1 to $2 \mathrm{~mm}$ in grain size (table 1, samples 1, 4, 5). Locally, bands of garnetiferous gneiss and schist have been mapped separately. Within the typical gray granulite are light-gray, discontinuous interlayers, no more than a few millime- 


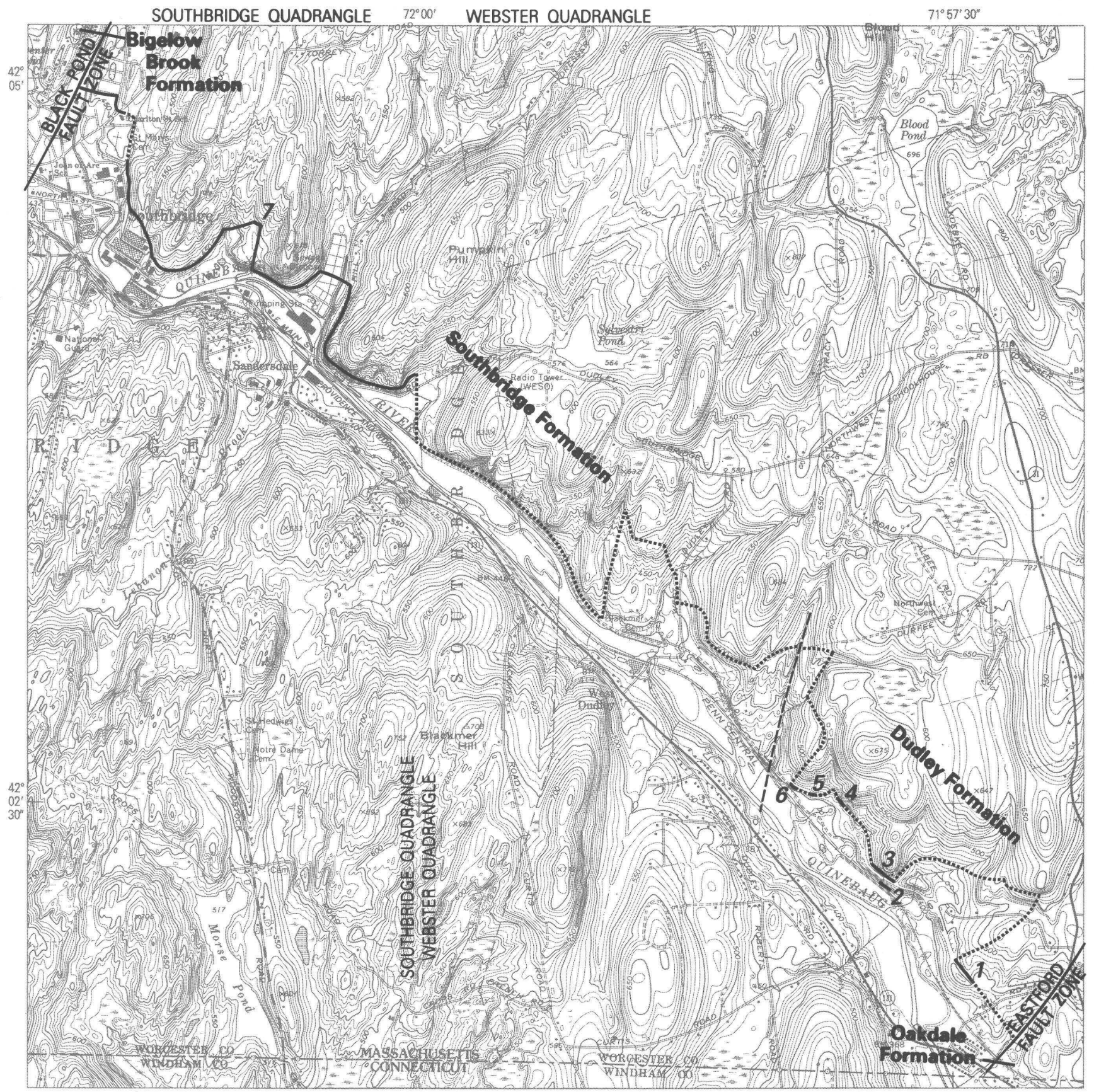

Base from U.S. Geological Survey, 1:24,000

Southbridge, 1967, photorevised 1979 , and Webster, 1969
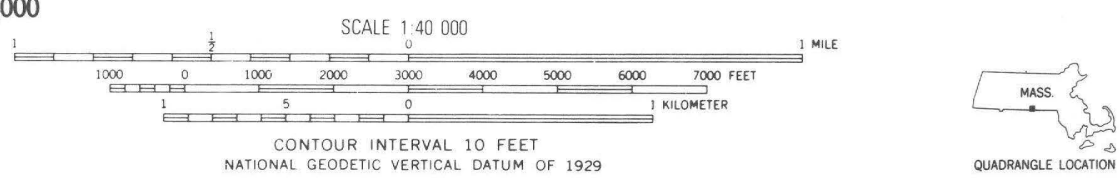

Figure 3. Map of parts of the Webster and Southbridge Quadrangles, Massachusetts, showing location of type sections of the Dudley and Southbridge Formations (reference section for the Paxton Group) (geologic data from Barosh, 1974, and Moore, 1978). Numbers show locations of described partial sections in appendix. The described parts of the section are shown by solid lines, with numbers keyed to descriptions in the appendix, and the rest by dotted lines that pass through areas of generally greater exposure. 


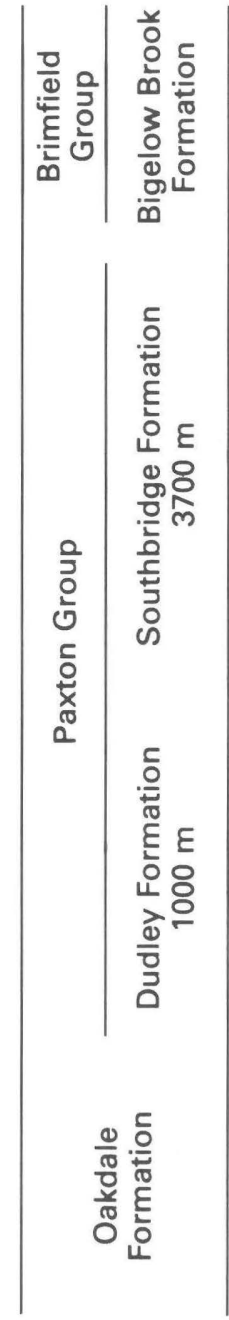

BIGELOW BROOK FORMATION-Browngray biotite-sillimanite-garnet gneiss and schist, rusty weathering in part, interbedded with some calc-silicate-and sulfidegraphite-bearing units. Thin to thick bedded.

SOUTHBRIDGE FORMATION-Medium- to dark-gray, interbedded fine- to coarsegrained schistose granulite and some thin beds, lenses, and nodules of lightgreenish-gray, calc-silicate-bearing granulite. Well to moderately bedded in thin to medium beds. Rare beds of mediumgray, medium-grained granulite and, near the top, beds and lenses of rusty-weathering sillimanite schist, dark-gray hornblende granulite, and very dark gray amphibolite. 10-25 percent pegmatite.

DUDLEY FORMATION-Medium- to darkgray, fine-grained schistose granulite and some interlayered thin beds, lenses, and nodules of light-greenish-gray, calc-silicate-bearing granulite. Well bedded in thin to medium beds. Very few interbeds of other lithologies. 10-20 percent pegmatite.

OAKDALE FORMATION-Medium- to darkgreenish-gray metasiltstone. Well bedded in thin beds that are commonly laminated. Laminae of calc-silicate minerals and calcite in places. Silicic in part and contains scattered lenses of silvery muscovite schist.

Figure 4. Columnar section showing the Paxton Group and bordering stratigraphic units.

ters thick, composed of fine-grained quartz, plagioclase, and a few percent biotite; these interlayers amount to about 10 percent of the granulite.

Calc-silicate-bearing beds are ubiquitious in the Paxton, but they range from rare to abundant in any part of the section. The calc-silicate minerals, generally diopside, actinolite-hornblende, garnet, and sphene, occur as laminae, narrow diffuse layers, lenses, or nodules within thin beds (table 1, samples 6-10). Minor amounts of calcite may also be present. The calc-silicate-bearing beds are denser and lighter colored than the schistose granulite. As the amount of calc-silicate minerals increases, the content of biotite generally decreases and the color changes to greenish gray, bluish gray, or gray green; the rock ultimately becomes a tough, granular, quartz-feldspar-calc-silicate granulite with as much as 30 percent calc-silicate minerals (table 1, samples 6-10). The calc-silicate rock weathers with a very distinctive rough, granular, pitted surface. Calc-silicate minerals also occur locally along small fractures in which the minerals are usually fine to medium grained or even coarse grained in places.

Local intervals within the Paxton contain thin beds of medium-gray schistose granulite, 1 to 10 centimeters (cm) (0.4 to 4 inches (in)) thick, interlayered with calcsilicate-bearing beds, 0.5 to $1 \mathrm{~cm}$ ( 0.2 to 0.4 in) thick. These sequences generally are evenly layered, presenting a distinctive pinstriped appearance. Such sequences are prominent in many areas of the Paxton.

The Paxton is generally well bedded in thin to medium beds. Contacts commonly are moderately gradational, but some are sharp and well marked. Strata in new road cuts and other recent exposures may appear thick bedded or massive, but weathering brings out the thinner bedding. Many beds, especially thin beds, are also laminated, and cross-lamination occurs locally. Thin beds may also show a slight grading that is most easily seen on a weathered profile. Schistose partings commonly are seen to grade from the coarser bed below.

Lithologies other than schistose granulite and calcsilicate-bearing granulite are present in the Paxton as lenses and thin beds mostly in the upper part. Lenses of light-gray, medium-grained, quartz-plagioclase granulite as much as $4 \mathrm{~m}$ thick occur in several places. Beds of amphibolite and sillimanite schist are also present. Also, mineralization related to the pegmatites has changed the composition of many beds. The pegmatite consists of quartz, microcline, and plagioclase with minor biotite, muscovite, lavender-pink garnet, graphite, and other accessories, and locally the schistose granulite may grade into a rock of similar composition. The composition varies according to amount of contained country rock (table 1, samples 13-17). The amount of microcline and muscovite generally increases, whereas the amount of plagioclase and biotite decreases, with increasing admixtures of the pegmatitic material. In addition, finer grained granitic material mineralogically related to the pegmatite occurs as veinlets a few millimeters thick, as trains of separate crystals, and, in places, as increased quartz content and minor amounts of microcline within schistose granulite.

\section{DUDLEY FORMATION}

The Dudley Formation appears to be transitional between finer grained metasiltstone of the Oakdale Formation and coarser grained, more thickly layered strata of the overlying Southbridge Formation. The Dudley consists of schistose granulite and calc-silicate-bearing beds typical of the Paxton. The schistose granulite is fine grained, generally thin bedded, and laminated in part. The formation is well to moderately well bedded. An equigranular, fine-grained texture predominates, except 
Hebron Formation
Paxton Group

Berwick Formation

Vassalboro Formation

Dudley Formation

Oakdale Formation

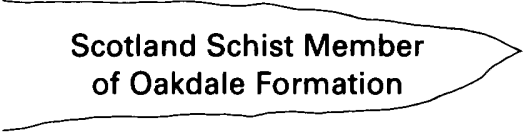

Scotland Schist Member

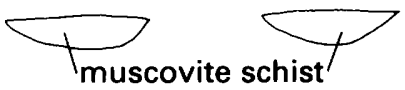

Gove Member of the

Berwick Formation

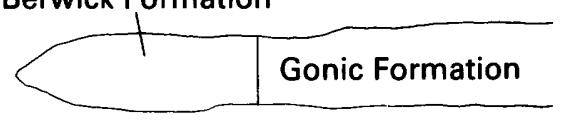

Berwick Formation

Fault-or-intrusive contact

Figure 5. Regional correlation of the Paxton Group (modified from Barosh and Pease, 1981).

for biotite-rich schistose partings where the biotite commonly is slightly coarser grained and some calc-silicatebearing granulite. Quartz and feldspar grains show no evidence of coarsening, even by contact metamorphism within or adjacent to intrusive bodies.

Both the upper and lower contacts of this formation appear to be comformable. The contact with the underlying Oakdale Formation is gradational over a stratigraphic interval of a few meters or tens of meters; it is readily delineated across eastern Connecticut and central Massachusetts. The contact with the overlying Southbridge Formation is less clearly defined, but it too appears to be gradational. The contact is placed where medium- to coarse-grained beds of the Southbridge first are commonly interlayered with the more uniformly fine grained Dudley. The position of this contact seldom can be delineated more closely than a stratigraphic interval of 30-50 m (98-164 feet (ft)).

The Dudley is poorly exposed in the lower part of its type section and moderately well exposed along a railroad grade in the upper part (see appendix for details). Strata typical of the formation are also well exposed south of the Quinebaug River in scattered outcrops 300 to $600 \mathrm{~m}$ (985 to $1,970 \mathrm{ft}$ ) on either side of Converse Road in the northeast corner of Woodstock, Conn. The upper and lower contacts are faulted in the type section. The maximum apparent exposed stratigraphic thickness is approximately $1,000 \mathrm{~m}(3,280 \mathrm{ft})$.

\section{SOUTHBRIDGE FORMATION}

The Southbridge Formation is distinguished from the Dudley by its more varied lithology, but is still a generally uniform unit. Like the Dudley, it is composed mostly of schistose granulite, but unlike the Dudley, these strata alternate from thin to thick bedded and from fine to coarse grained. Calc-silicate-bearing beds are more common than in the Dudley, being most abundant in the middle and upper parts.

The uppermost part of the Southbridge contains local interlayers of sillimanite schist, sulfidic schist, and amphibolite which are typical of the overlying Bigelow Brook Formation. Some typical rock types are as follows: rusty-weathering schistose granulite with appreciable amounts of sillimanite and lavender-pink garnet; sulfidic schists and schistose granulite composed of quartz, feldspar, muscovite, and graphite with or without garnet and sillimanite, that weather orange-brown and yellow; darkgray, medium- to fine-grained, well-foliated schistose granulite made up of hornblende, biotite, feldspar, and quartz, some with garnet (table 1, samples 11, 12); coarser grained, darker gray schistose granulite composed of hornblende, feldspar, and quartz; and dark-gray, more massive, coarse-grained amphibolite.

The surface trace of the contact with the overlying Bigelow Brook Formation is a fault along much of its extent, but in places the stratigraphic contact appears to be gradational and conformable. Peper and others (1975, 
Table 1. Mineralogic composition of rock samples from the Southbridge Formation

[In percent. Sample numbers keyed to description of rock types in text and stratigraphic section localities described in appendix; empty cells mean mineral not present; tr, trace. Petrology by G.E. Moore, Jr.]

\begin{tabular}{|c|c|c|c|c|c|c|c|c|c|c|c|c|c|c|c|c|c|}
\hline \multirow{3}{*}{ 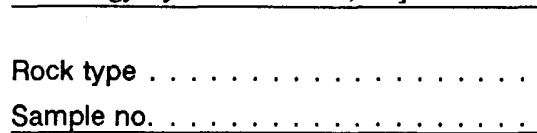 } & \multicolumn{12}{|c|}{ Schistose granulite } & & & & & \\
\hline & \multicolumn{4}{|c|}{ Typical } & $\begin{array}{l}\text { Muscovite- } \\
\text { bearing }\end{array}$ & \multicolumn{5}{|c|}{ Calc-silicate-bearing } & \multicolumn{2}{|c|}{$\begin{array}{l}\text { Hornblende- } \\
\text { rich }\end{array}$} & \multicolumn{5}{|c|}{ Pegmatitic-bearing rock } \\
\hline & 1 & 2 & 3 & 4 & 5 & 6 & 7 & 8 & 9 & 10 & 11 & 12 & 13 & 14 & 15 & 16 & 17 \\
\hline 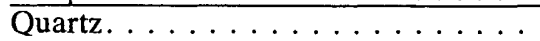 & 47.5 & 43.9 & 46.9 & 33.3 & 31.5 & 48.5 & 40.0 & 45.3 & 30.5 & 18.9 & 50.6 & 17.2 & 34.2 & 39.1 & 29.0 & 26.9 & 32.0 \\
\hline $\begin{array}{l}\text { Plagioclase } \ldots \ldots \ldots \ldots \\
\quad(\% \text { anorthite content }) \ldots \ldots \ldots \ldots\end{array}$ & $\begin{array}{l}27.2 \\
(51)\end{array}$ & $\begin{array}{l}31.8 \\
(50)\end{array}$ & $\begin{array}{l}30.2 \\
(50)\end{array}$ & $\begin{array}{l}48.1 \\
(45)\end{array}$ & $\begin{array}{l}26.9 \\
(37)\end{array}$ & $\begin{array}{l}24.9 \\
(35)\end{array}$ & $\begin{array}{l}31.8 \\
(40)\end{array}$ & $\begin{array}{l}29.5 \\
(48)\end{array}$ & $\begin{array}{l}29.0 \\
(48)\end{array}$ & $\begin{array}{l}40.2 \\
(86)\end{array}$ & $\begin{array}{l}22.1 \\
(69)\end{array}$ & $\begin{array}{l}33.9 \\
(54)\end{array}$ & $\begin{array}{c}37.8 \\
(67 ?)\end{array}$ & $\begin{array}{l}25.7 \\
(48)\end{array}$ & $\begin{array}{l}19.8 \\
(22)\end{array}$ & 26.5 & $\begin{array}{l}27.2 \\
(37)\end{array}$ \\
\hline Microcline $\ldots \ldots \ldots \ldots \ldots$ & & & tr & & & & & 0.2 & & & & & 3.4 & 7.7 & 36.6 & 38.8 & 28.8 \\
\hline Biotite . . . . . . . . . . & 18.7 & 18.5 & 18.8 & 15.6 & 19.9 & 10.8 & 17.3 & 13.6 & 20.2 & & 16.0 & 26.4 & $\operatorname{tr}$ & 22.8 & 10.2 & 1.6 & 6.2 \\
\hline Chlorite . . . . . . . . . . . & 1.9 & 4.1 & & & & & & & & & $\operatorname{tr}$ & $\operatorname{tr}$ & 15.9 & $\operatorname{tr}$ & & 3.1 & \\
\hline Muscovite. . . . . . . . . . . . & 2.1 & & $\operatorname{tr}$ & & 15.3 & & & & & & & & & 3.3 & 3.5 & 2.5 & 5.1 \\
\hline Tremolite-actinolite . . . . . . . & & 0.2 & & & & 13.9 & & & $\operatorname{tr}$ & & & & 5.5 & & & & \\
\hline Hornblende $\ldots \ldots \ldots \ldots \ldots$ & & & 3.4 & & & & 3.0 & 2.2 & & 2.7 & 9.5 & 19.8 & & & & & \\
\hline Diopside . . . . . . . . . . . & & & & & & & 5.9 & 6.8 & 17.6 & 31.4 & & & & & & & \\
\hline Garnet. . . . . . . . . . . . . & 0.7 & & $\operatorname{tr}$ & 1.6 & 4.1 & & & & & & & & & & & & 0.1 \\
\hline 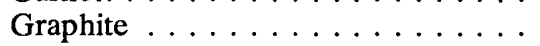 & & $\operatorname{tr}$ & & tr & 1.9 & 1.2 & & $\operatorname{tr}$ & & 0.1 & $\operatorname{tr}$ & 0.9 & $\operatorname{tr}$ & & & & \\
\hline Apatite $\ldots \ldots \ldots \ldots \ldots \ldots$ & $\operatorname{tr}$ & $\operatorname{tr}$ & $\operatorname{tr}$ & $\operatorname{tr}$ & & $\operatorname{tr}$ & $\operatorname{tr}$ & $\operatorname{tr}$ & $\operatorname{tr}$ & $\operatorname{tr}$ & $\operatorname{tr}$ & 1.4 & $\operatorname{tr}$ & $\operatorname{tr}$ & & $\mathrm{tr}$ & $\operatorname{tr}$ \\
\hline 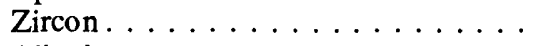 & $\operatorname{tr}$ & tr & $\operatorname{tr}$ & $\operatorname{tr}$ & & $\operatorname{tr}$ & $\operatorname{tr}$ & $\operatorname{tr}$ & $\operatorname{tr}$ & $\operatorname{tr}$ & $\operatorname{tr}$ & 0.1 & $\operatorname{tr}$ & tr & $\operatorname{tr}$ & $\operatorname{tr}$ & $\operatorname{tr}$ \\
\hline Allanite . . . . . . . . . . & $\operatorname{tr}$ & tr & $\operatorname{tr}$ & & & & $\operatorname{tr}$ & $\operatorname{tr}$ & $\operatorname{tr}$ & & $\operatorname{tr}$ & $\operatorname{tr}$ & & & & & $\operatorname{tr}$ \\
\hline Magnetite-hematite. . . . . . . . . & $\operatorname{tr}$ & & & tr & & tr & $\operatorname{tr}$ & & & $\operatorname{tr}$ & & & & $\operatorname{tr}$ & $\mathrm{tr}$ & & \\
\hline Epidote-zoisite $\ldots \ldots \ldots \ldots \ldots$ & $\mathrm{tr}$ & & & & & & & & & & & & & & & $\operatorname{tr}$ & $\operatorname{tr}$ \\
\hline Rutile $\ldots \ldots \ldots \ldots \ldots \ldots$ & $\operatorname{tr}$ & & & $\operatorname{tr}$ & & & & & & & & & & $\operatorname{tr}$ & $\operatorname{tr}$ & & \\
\hline Sphene $\ldots \ldots \ldots \ldots \ldots \ldots$ & & & $\operatorname{tr}$ & & & $\operatorname{tr}$ & $\operatorname{tr}$ & $\operatorname{tr}$ & $\operatorname{tr}$ & $\operatorname{tr}$ & $\operatorname{tr}$ & & $\operatorname{tr}$ & & tr & & \\
\hline Pyrite-hematite $\ldots \ldots \ldots \ldots \ldots$ & & $\operatorname{tr}$ & $\operatorname{tr}$ & & & $\operatorname{tr}$ & & & $\operatorname{tr}$ & & $\operatorname{tr}$ & 0.3 & 2.3 & & & & \\
\hline Tourmaline . . . . . . . . . . . . . & & & $\operatorname{tr}$ & & & & & & & & & & & & & & \\
\hline Calcite. . . . . . . . . . & $\operatorname{tr}$ & & & & & & & & & 4.3 & & & & & & & \\
\hline Trace amount $\ldots \ldots \ldots \ldots \ldots$ & 1.9 & 1.5 & 0.7 & 1.4 & 0.4 & 0.7 & 2.0 & 2.4 & 2.7 & 2.4 & 1.8 & 0 & 0.9 & 1.4 & 0.9 & 0.6 & 0.6 \\
\hline
\end{tabular}


p. 6) noted an increase in the thickness and number of sillimanite schist and gneiss beds over an interval of a few tens of meters at the contact in the Worcester area. At a gradational contact near Moodus, Conn., a few widely spaced 1-m (3-ft) interbeds of sillimanite schist occur in the upper Southbridge; these increase in number over about $30 \mathrm{~m}(98 \mathrm{ft})$ to form half the strata at the base of the Bigelow Brook Formation. The contact is placed where sillimanite schist and sulfidic schist first appear to dominate the section.

Pease (1972) divided the Southbridge Formation in the Eastford Quadrangle into a lower and an upper member. Much of the lower member is less well layered and is more uniform than the upper member and is characterized by the presence of potassium feldspar megacrysts. This rock type probably represents partially metasomatized strata perhaps derived from massive infusion of pegmatitic feldspar rather than a stratigraphic unit as interpreted by Pease; it has not been mapped outside the Eastford Quadrangle. Felsic rock, similar in composition to pegmatite, also is common in the middle part of the formation, where it makes up the bulk of some outcrops. The rock, which is finer grained than pegmatite, is very light gray to white, medium grained, granular, composed of quartz, plagioclase, 2 to 3 percent biotite, and as much as 5 percent microcline. The microcline is white and occurs in ovoid grains with granulated borders about $5 \mathrm{~mm}$ across by $10 \mathrm{~mm}$ long.

The maximum apparent stratigraphic thickness of the Southbridge Formation is about $3,700 \mathrm{~m}(12,140 \mathrm{ft})$ in the type section. The measured thickness of the type section in the Southbridge Quadrangle is $1,893 \mathrm{~m}(6,211$ $\mathrm{ft}$ ) (appendix), and the estimated thickness of the extended type section in the Webster Quadrangle is $1,800 \mathrm{~m}$ $(5,906 \mathrm{ft})$. Pease (1972) estimated a thickness of $4,200 \mathrm{~m}$ $(13,780 \mathrm{ft})$ in the Eastford Quadrangle, but this includes $1,550 \mathrm{~m}(5,085 \mathrm{ft})$ for the questionable lower member that may possibly be thickened by an infusion of pegmatitic material.

\section{PAXTON GROUP UNDIVIDED}

Strata of the Paxton Group have been traced in several northeast-trending fault blocks from east-central Connecticut into Maine. It has been divided into the Southbridge and Dudley Formations thus far only in central Massachusetts and northeastern Connecticut; outside of this area it is undivided. Detailed field mapping should lead to the extension of these formations over a much wider area. Subtle but accumulative changes in facies across broad areas of poor exposure, however, will probably preclude its division everywhere. The more distant undivided Paxton is still composed of its characteristic lithologies and remains a valid and very useful stratigraphic unit.
The Paxton becomes generally finer grained southeastward across New Hampshire and adjacent Massachusetts and contains interbeds of metasiltstone in its southeastern part, but it still is clearly distinguishable from the more homogeneous metasiltstone of the Oakdale, which also becomes finer grained to the southeast. A distinctive "pinstripe" lithology consisting of thinly interbedded schistose granulite and calc-silicate-bearing granulite is a characteristic lithology of the Paxton Group in New Hampshire and Maine. The Rye Formation (Novotny, 1969) of the New Hampshire coast consists largely of this "pinstripe" lithology and is correlated with the Paxton (Barosh, 1984). Farther southeast in another fault block, granite forming the Isle of Shoals contains pendants of schistose granulite that are correlated with the Paxton. These contain a few thin, interlayered units of thin-bedded, laminated amphibolite.

The total stratigraphic thickness of the Paxton Group cannot be determined too closely as it is cut by faults of indeterminate displacement, but an approximate thickness can be given. The maximum exposed stratigraphic thickness along the type section in the Southbridge and Webster Quadrangles is approximately 4,700 m $(15,421$ $\mathrm{ft})$. Farther north in Massachusetts and New Hampshire the section is incomplete owing to faulting and therefore appears somewhat thinner.

\section{GEOMORPHIC EXPRESSION}

The Paxton Group in the type area is intermediate in resistance to weathering. It lies between the valleyforming Oakdale to the east and the ridge-forming Brimfield to the west. The Dudley Formation is less well exposed than the overlying Southbridge, which forms intermediate slopes against the upland of the Brimfield west of Worcester. This relative degree of weathering of the Paxton is the same farther north, where the Paxton and Oakdale strata form the coastal lowlands of New Hampshire and southern Maine.

The rock types within the Paxton vary greatly in their resistance to erosion. Pegmatite appears to be the most resistant rock in much of the area and commonly makes up more than 50 percent of the total outcrop in the upper part of the group. Many outcrops consist of a meter or two of pegmatite with several centimeters of country rock exposed at top and bottom; the schistose granulite is next in order of resistance, and calc-silicatebearing granulite is least resistant. The relative thickness of these rock types as exposed in the field and in the measured sections is thus probably not a true measure of their abundance in the Paxton.

\section{AGE}

No fossils have been found in the Paxton Group or in any stratigraphic unit associated with the Paxton. 
Radiometric dates of related igneous rocks intrusive into the Paxton and related stratigraphic units do provide possible minimum ages. An approximate age of 395 m.y. (Zartman and Naylor, 1984) has been assigned to the Canterbury Gneiss, which intrudes the Oakdale. An approximate age of 440 m.y. (R.E. Zartman, pers. commun., 1980) has been assigned to the Hedgehog Hill sill (Peper and Pease, 1975), which intrudes the Hamilton Reservoir Formation of the Brimfield Group, which overlies the Paxton at a much higher stratigraphic level (Peper and others, 1975). Thus the Paxton is at least as old as pre-Late Ordovician. Detrital zircons collected from the Oakdale Formation in east-central Massachusetts give a late Middle Proterozoic age of 1,188 m.y. (Aleinikoff and others, 1979). This date may represent a maximum possible age for the Oakdale.

In New Hampshire, the Paxton and Brimfield Groups are intruded by the Massabesic Gneiss Complex, a migmatitic pegmatitic granite (Barosh and others, 1977, p. 45-48). Semidigested Paxton strata along its southeast side, in particular, imparts a "gneissoid" texture to the Massabesic. Zircon dated as 600 to 650 m.y. old from the migmatitic Massabesic (Besancon and others, 1977; Lyons and others, 1982) appears to be from the Paxton and may also indicate a maximum age for the Paxton. The Paxton Group is thus pre-Late Ordovician and provisionally is considered Late Proterozoic in age. In addition, the conformity of early thrust faults affecting the Paxton with Late Proterozoic syntectonic structures to the east of the Lake Char fault (fig. 1) suggests that the structures developed at the same time and, if so, would indicate a Proterozoic age for the Paxton.

\section{CORRELATION}

The Oakdale-Paxton-Brimfield sequence has now been followed into southern Maine, and the Paxton Group has been correlated with units to the north, both along strike and in separate structural blocks between the Fitchburg pluton and the Clinton-Newbury fault zone (Barosh and others, 1977; Barosh and Pease, 1981; Barosh, 1984) (fig. 1).

In New Hampshire, strata of the Paxton Group are repeated in two separate fault blocks and also correlate with the Rye Formation on the coast (Barosh, 1984, fig. 9), and pendants of strata on the Isle of Shoals appear to be part of a fourth block. The Paxton Group along with part of the Oakdale Formation can be traced into the Berwick Formation in southern Maine (Barosh and others, 1977; Barosh and Pease, 1981) (fig. 5). The Gove Member of the Berwick Formation and the Gonic Formation in Maine represent the Scotland Schist Member of the Oakdale Formation (Barosh and Pease, 1981; Pease, in press).
The undivided Paxton continues farther northeastward into Maine as the Vassalboro Formation, and apparently as the Bucksport Formation as well. The Berwick continues north-northeast past the latitude of Portland, Maine, as the Vassalboro Formation. Near Lewiston, Maine, the Vassalboro contains thin belts of rusty schist mapped as Waterville Formation by Osberg and others (1985). These correlate with schist lenses at the top of the Paxton; however, the Waterville farther north near its type area is a different and apparently much younger stratigraphic unit. The Bucksport Formation lies in a different fault block to the southeast along the central Maine coast (Osberg and others, 1985) and is composed mainly of strata characteristic of the Paxton. It is tentatively correlated with the Paxton on the basis that it is of similar lithology and order of thickness and is adjacent to strata resembling the Brimfield in the Casco Bay Group. Part of the Bucksport north of Penobscot Bay is composed of metasiltstone, and there it may contain strata equivalent to the Oakdale as well.

The present indicated extent of the Paxton Group is about $450 \mathrm{~km}$ (280 miles (mi)) from near Moodus, Conn., to the north side of Penobscot Bay on the central Maine coast. It is thus one of the more widespread stratigraphic units in New England.

\section{ORIGINAL LITHOLOGY AND ENVIRONMENT OF DEPOSITION}

The composition, texture, and sedimentary structures of the Paxton Group indicate that it consists of a very thick, rather monotonous pile of metamorphosed graywacke with very thin shaly layers and many limy intervals that probably vary from zones with calcite cement to calcareous graywacke and mudstone; a few beds and lenses of cleaner, more quartzose sandstone are interlayered in places, and rare thicker shale beds occur near the top. Calcareous concretions or disrupted calcareous beds are present in some intervals. The graywacke was probably derived from sediments containing a large component of pyroclastic and other volcanic debris. Intervals with calcareous cement and mud provided the material for the calc-silicate minerals, and a few very limy beds and lenses or, less likely, basaltic tuff later formed amphibolites. Lenses and beds of shale, containing aluminous-rich clay, interbedded near the top of the unit are represented by sillimanite schist intervals in the section.

The very thin to medium beds, which are commonly graded, suggest that the sands were deposited on a marine slope at some intermediate distance offshore. Turbidity currents were common, as inferred by graded sand beds and, more commonly, by thin mud cappings from slowly settling finer grained material. The general 
increase upward in grain size, thickness of bedding, and greater lithologic heterogeneity suggests that deposition took place progressively closer to shore and source with time. These changes within the Paxton appear to be a subtle reflection of the same general changing environment with time, as indicated by the change from the uniform silt of the Oakdale to the more heterogeneous deposits in the Brimfield Group. A progressive decrease in grain size and apparent increase in lime content to the southeast across different structural blocks of the Paxton in New Hampshire indicates the source lay to the northwest.

\section{REFERENCES}

Aleinikoff, J.N., Zartman, R.E., and Lyons, J.B., 1979, U-THPB geochronology of the Massabesic Gneiss and the granite near Milford, south-central New Hampshire: New evidence for Avalonion basement and Taconic and Alleghenian disturbances in eastern New England: Contribution to Mineralogy and Petrology 71, p. 1-11.

Barosh, P.J., 1974, Preliminary bedrock geologic map of the Webster Quadrangle, Massachusetts-Connecticut: U.S. Geological Survey Open-File Report 74-192, 2 p., scale 1:24,000.

1976, Stratigraphy of the Webster-Worcester region, Massachusetts, in Cameron, Barry, ed., Geology of southeastern New England (New England Intercollegiate Geologic Conference, 68th annual meeting guide book): Princeton, N.J., Science Press, p. 352-365.

1977, Preliminary map showing bedrock geology superposed on aeromagnetic base map of the Worcester region, Massachusetts, Connecticut, and Rhode Island: U.S. Geological Survey Open-File Report 77-131, 46 p., scale 1:125,000.

1984, Regional geology and tectonic history of southeastern New England, in Hanson, L.S., ed., Geology of the coastal lowlands from Boston, MA to Kennebunk, ME (New England Intercollegiate Geologic Conference, 76th annual meeting guide book): Salem, Mass., Salem State College, p. 1-35.

Barosh, P.J., Fahey, R.J., and Pease, M.H., Jr., 1977, Preliminary compilation of the bedrock geology of the land area of the Boston $2^{\circ}$ sheet, Massachusetts, Connecticut, Rhode Island and New Hampshire: U.S. Geological Survey OpenFile Report 77-285, 142 p., scale 1:125,000.

Barosh, P.J., and Pease, M.H., Jr., 1981, Correlation of the Oakdale and Paxton Formations with their equivalents from eastern Connecticut to southern Maine [abs.]: Geological Society of America, Abstracts with Programs, v. 13, p. 122.

Besancon, J.R., Gaudette, H.E., and Nylor, R.S., 1977, Age of the Massabesic Gneiss, southeastern New Hampshire:
Geological Society of America, Abstracts with Programs, v. 9 , no. 2 .

Dixon, H.R., and Lundgren, Lawrence, Jr., 1968, Structure of eastern Connecticut, in Zen, E-an, White, W.S., and Hadley, J.B., eds., Studies of Appalachian geology, p. 219-230.

Emerson, B.K., 1898, Geology of old Hampshire County, Mass., comprising Franklin, Hampshire, and Hampden Counties: U.S. Geological Survey Monograph 29, 790 p. 1917, Geology of Massachusetts and Rhode Island: U.S. Geological Survey Bulletin 597, 289 p., map scale 1:250,000.

Gregory, H.E., and Robinson, H.H., 1907, Preliminary geologic map of Connecticut: Connecticut Geological and Natural History Survey Bulletin 7, 39 p.

Grew, E.S., 1970, Geology of the Pennsylvanian and prePennsylvanian rocks of the Worcester area, Massachusetts: Ph.D. thesis, Harvard University, 263 p.

Lyons, J.B., Boudette, E.L., and Aleinikoff, J.N., 1982, The Avalon and Gander zones in central eastern New England, in St.-Julien, Pierre, and Belund, Jacques, Jr., eds., Major structural zones and faults of the northern Appalachians: Geological Society of Canada Special Paper 24, p. 43-66.

Moore, G.E., Jr., 1978, Preliminary bedrock, surficial, and structural data maps of the Southbridge Quadrangle, Massachsuetts and Connecticut: U.S. Geological Survey Open-File Map 78-220, 16 p., scale 1:24,000.

Novotny, R.F., 1969, The geology of the seacoast region, New Hampshire: New Hampshire Department of Resources and Economic Development (Concord) 4/p. geologic map, scale 1:62,500 (Dover and Exeter 15' quadrangles).

Osberg, P.H., Hussey, A.M., II, and Boone, G.M., eds., 1985, Bedrock geologic map of Maine: Maine Geological Survey, scale $1: 500,000$.

Pease, M.H., Jr., 1972, Geology of the Eastford Quadrangle, Windham and Tolland Counties, Connecticut: U.S. Geological Survey Geologic Quadrangle Map GQ-1023, 3 p., scale $1: 24,000$.

in press, Correlation of the Oakdale Formation and Paxton Group of central Massachusetts with strata in northeastern Connecticut: U.S. Geological Survey Bulletin.

Pease, M.H., Jr., and Barosh, P.J., 1981, Distribution and structural significance of the Oakdale Formation in northeastern Connecticut, in Boothroyd, J.S., and Hermes, O.D., eds., Geological field studies in Rhode Island and adjacent areas (New England Intercollegiate Geologic Conference, 73d annual meeting guide book): Kingston, University of Rhode Island, p. 17-34.

Peck, J.H., 1975, Preliminary bedrock geologic map of the Clinton Quadrangle, Worcester County, Massachusetts: U.S. Geological Survey Open-File Report 75-658, 30 p., scale 1:24,000.

Peper, J.D., and Pease, M.H., Jr., 1975, Geology of the Westford Quadrangle, Connecticut: U.S. Geological Survey Geologic Quadrangle Map GQ-1214.

1976, Summary of stratigraphy in the Brimfield area, Connecticut and Massachusetts, in Page, L.R., ed., Contributions to the stratigraphy of New England: Geological Society of America Memoir 148, p. 253-270. 
Peper, J.D., Pease, M.H., Jr., and Seiders, V.M., 1975, Stratigraphic and structural relationships of the Brimfield Group in northeast-central Connecticut and adjacent Massachusetts: U.S. Geological Survey Bulletin 1389, 31 p.

Perry, J.H., and Emerson, B.K., 1903, The geology of Worcester, Massachusetts: Worcester, Mass., Worcester Natural History Society, 166 p.
Rodgers, John, compiler, 1985, Bedrock geological map of Connecticut: Connecticut Geological and Natural History Survey, scale 1:225,000.

Zartman, R.E., and Naylor, R.S., 1984, Structural implications of some radiometric ages of igneous rocks in southeastern New England: Geological Society of America Bulletin, v. 95 , no. 5, p. 522-539. 


\section{Stratigraphic Description of the Upper Part of the Type Section of the Southbridge Formation}

The type section of the Southbridge Formation is in the Southbridge and Webster Quadrangles, Mass., along the northeast side of the Quinebaug River. The section extends from the base where an unused railroad bed crosses a side stream $1,036 \mathrm{~m}(3,400 \mathrm{ft})$ southeast of the bridge over the river at West Dudley $(380,700 \mathrm{ft}$ north; $471,675 \mathrm{ft}$ east, Massachusetts Coordinate Grid System), and thence northwestward along an old railroad cut to the edge of the Southbridge Quadrangle $(387,500 \mathrm{ft}$ north; $464,075 \mathrm{ft}$ east, Mass. Coord.). There it is offset northward to a point $350 \mathrm{ft}$ north of the Dudley Hill Road at the border of the two quadrangles $(389,080 \mathrm{ft}$ north; $466,520 \mathrm{ft}$ east, Mass. Coord.), and thence northwesterly along the steep slopes on the north side of the Quinebaug River and around the buildings of the American Optical Company to an unnamed brook just east of the Charlton Street School. At that point it is offset north along the brook to the school, and thence northwesterly to a point on Cady Brook at the end of Fairlawn Avenue (395,715

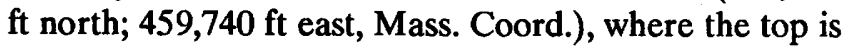
against the Black Pond fault. The description below is of the upper half of the Southbridge. This is the only part of the Paxton Group for which there is detailed petrographic work. However, the rock types sampled occur throughout the section and the mineralogic compositions are considered representative of the entire Paxton.

In the measured part of the type section of the Southbridge about 60 percent is covered, 10 percent is pegmatite, 2 percent is calc-silicate-bearing granulite, and 28 percent is gray, schistose granulite and schist. The metasedimentary rock exposed in this part of the section is about 93 percent gray, schistose granulite and schist and about 7 percent calc-silicate-bearing granulite.

Numbers refer to localities of partial sections measured (fig. 3).

\section{Locality 7}

Exposure measured by means of a Jacob's staff and clinometer, starting at a point on the east edge of the Southbridge Quadrangle 110 m (350 ft) north of the Dudley Hill Road, thence upsection northwesterly along the steep slopes on the north side of the Quinebaug River and around the buildings of the American Optical Company to an unnamed brook just east of the Charlton Street School, thence offset north along the brook to the school, and thence northwesterly to a point on Cady Brook at the end of Fairlawn Avenue. Description is given from top toward base.
Fault contact with the Bigelow Brook Formation at Black Pond fault along Cady Brook

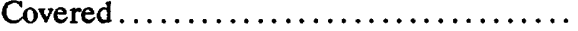

Schistose granulite, fine- to mediumgrained, greenish-gray, contains quartz, feldspar, chlorite, graphite, and pyrite (table 1, sample 2); partly silicified, slickensided surfaces, irregular pods of quartz

Covered (along Fairlawn Avenue) (offset

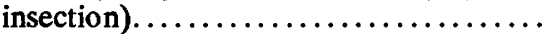

Pegmatite, foliated, contains subhedral feldspar crystals to $15 \mathrm{~cm}$ (6 in) in diameter.

Schistose granulite, fine- to mediumgrained, light-gray, granulated, rustyweathering, containing quartz, feldspar, and biotite, chloritized, pegmatitic pods

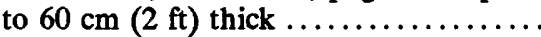

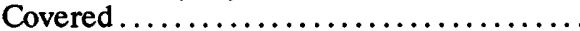

Schistose granulite, fine- to mediumgrained, light-gray to blue-gray, granular, quartz, feldspar, 5 to 10 percent biotite. Part of granulite is bleached, chloritized, and greenish gray. Some has layers of fine-grained quartz and feldspar 2 to 5 $\mathrm{mm}$ ( 0.08 to $0.20 \mathrm{in})$ thick. Foliated pegmatite $1 \mathrm{~m}(3 \mathrm{ft})$ thick............ Covered (across a north-south side street) Schistose granulite, like next exposure above (table 1, sample 1); $2 \mathrm{~m}$ (6 ft) of pegma-

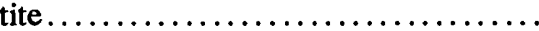

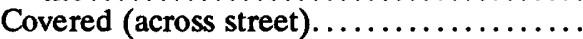

Schistose granulite, fine- to mediumgrained, medium-gray to light-blue-gray; rusty-weathering, very quartzose beds with \pm 1 percent pyrite (table 1 , sample 13). Pegmatite pods to $15 \mathrm{~cm}$ (6 in) thick (in schoolyard) $\ldots \ldots \ldots \ldots \ldots \ldots \ldots \ldots$

Covered intervals, three, alternating with three outcrops of fine-grained, mediumgray, slightly schistose quartz-feldsparbiotite granulite containing discontinuous layers 2 to $10 \mathrm{~mm}(0.1$ to $0.4 \mathrm{in})$ thick of vitreous quartz and quartzfeldspar and 10 percent greenish-gray calc-silicate granulite in beds to $5 \mathrm{~cm}$ (2 in) thick; $42.7 \mathrm{~m}$ (140 ft) covered, $7.6 \mathrm{~m}$ $(25 \mathrm{ft})$ granulite (offset from brook just east of Charlton Street school) ........

Covered interval, $1.5 \mathrm{~m}(5 \mathrm{ft})$ of foliated pegmatite near middle ..............

Granulite, fine- to medium-grained, light- to medium-gray, 10 percent calc-silicate granulite and 40 percent pegmatite .....

Covered intervals, five, alternating with five outcrops of foliated pegmatite, and layers of fine- to medium-grained, light-gray, schistose granulite as much as $1.5 \mathrm{~m}(5 \mathrm{ft})$ thick; $35 \mathrm{~m}$ (115 ft) covered, $13.7 \mathrm{~m}$ (45 $\mathrm{ft})$ pegmatite, $3.1 \mathrm{~m}(10 \mathrm{ft})$ of schistose granulite (offset $152 \mathrm{~m}(500 \mathrm{ft})$ south)..

Schistose granulite, two layers, fine- to coarse-grained, medium-gray, containing quartz, feldspar, and biotite with discontinuous layers of coarse-grained vitreous

\begin{tabular}{rr}
\multicolumn{2}{c}{ Thickness } \\
Meters & Foet \\
& \\
& \\
21.6 & 71 \\
& \\
& \\
& \\
& \\
116.0 & 380 \\
& \\
6.1 & 20 \\
& \\
& \\
10.7 & 35 \\
9.1 & 30
\end{tabular}

$\begin{array}{ll}3.0 & 10 \\ 6.1 & 20\end{array}$


quartz and quartz and feldspar 2-6 mm (0.2 in) thick; 15 percent nodules and thin beds of gray-green quartz-feldspardiopside calc-silicate granulite; and 25 percent pods of foliated pegmatite, alternating with two covered intervals, $6.7 \mathrm{~m}$ $(22 \mathrm{ft})$ of schistose granulite, $1.5 \mathrm{~m}(5 \mathrm{ft})$ of calc-silicate-bearing granulite, $2.4 \mathrm{~m}$ ( 8 $\mathrm{ft}$ ) of pegmatite, $13.7 \mathrm{~m}(45 \mathrm{ft})$ covered. (This unit and following three are along road.) ......................

Schistose granulite, $20.7 \mathrm{~m}$ (68 ft); calcsilicate, $4.9 \mathrm{~m}$ (16 ft); pegmatite, $7.9 \mathrm{~m}$ $(26 \mathrm{ft})$; all like that of unit above.......

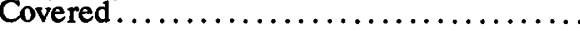

Schistose granulite, two bands, fine- to coarse-grained, light- to medium-gray, granular to slightly schistose, containing quartz, feldspar, biotite, and calc-silicate minerals; discontinuous layers of quartz 1 to $5 \mathrm{~mm}$ (0.04 to $0.2 \mathrm{in}$ ) thick, thin beds of gray-green quartz-feldspar-diopside granulite, and pods of foliated pegmatite to $1 \mathrm{~m}(3 \mathrm{ft})$ thick, and $13.7-\mathrm{m}(45-\mathrm{ft})$ covered interval near top of unit (across

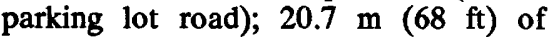
schistose granulite, $4.6 \mathrm{~m}(15 \mathrm{ft})$ of calc-

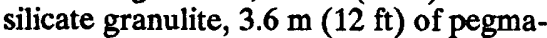
tite............................

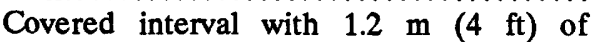

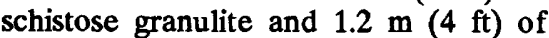
pegmatite near bottom of unit .........

Pegmatite, foliated in pods to $3.6 \mathrm{~m}(12 \mathrm{ft})$ thick; bands and septae of gray, schistose granulite as much as $1.5 \mathrm{~m}$ ( $5 \mathrm{ft})$ thick; 3 $\mathrm{m}(10 \mathrm{ft})$ of schistose granulite; $18.3 \mathrm{~m}$

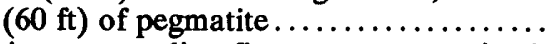

Schistose granulite, fine- to coarse-grained, medium-gray, containing quartz, feldspar, and biotite with 10 percent beds and nodules ofgray-green quartz-feldspardiopside calc-silicate granulite, 10 percent pegmatite, and 25 percent covered.

Schistose granulite, like interval above, with $3.4 \mathrm{~m} \mathrm{(11} \mathrm{ft)} \mathrm{of} \mathrm{calc-silicate-bearing} \mathrm{gra-}$

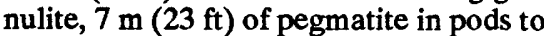
$1.2 \mathrm{~m}$ (4 ft) thick; one pegmatite is foliated to very highly sheared (table 1 , sample 16). (Unit extends to crest of the 178-m (570-ft) knob northeast of American Optical Company.) ..............

Covered intervals alternating with many thin bands of gray, schistose granulite and pegmatite and minor calc-silicatebearing granulite; $7.3 \mathrm{~m}(24 \mathrm{ft})$ of schistose granulite, $8.8 \mathrm{~m}(29 \mathrm{ft})$ of pegmatite, $0.6 \mathrm{~m}(2 \mathrm{ft})$ of calc-silicate-

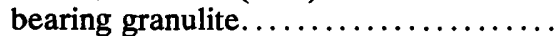

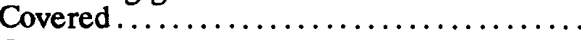

Calc-silicate-bearing granulite, fine- to coarse-grained, light-greenish-gray, containing quartz, feldspar, diopside, and many light-gray quartz-feldspar folia 1.5 to $10 \mathrm{~mm}$ (0.1 to $0.4 \mathrm{in}$ ) thick (table 1 ,

\section{Thickness \\ Meters Feet}

Moet

$24.4 \quad 80$

$33.5 \quad 110$

$36.6 \quad 120$

$42.7 \quad 140$

16.8

47.2

$71.6 \quad 235$

$21.3 \quad 70$ sample 10). Unit highly folded and has axial plane cleavage .................

Covered intervals alternating with thin bands of gray, schistose granulite and pegmatite; schistose granulite, fine to coarse grained, medium gray, containing quartz, feldspar, and biotite; $3.7 \mathrm{~m}$ (12 ft)

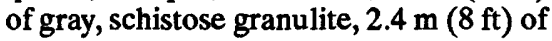
pegmatite

Schistose granulite, gray like that in unit

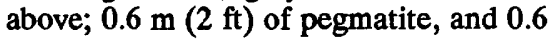
$\mathrm{m}(2 \mathrm{ft})$ of calc-silicate-bearing granulite

Covered intervals alternating with many thin bands of gray, schistose granulite and

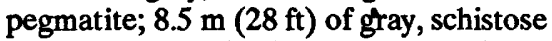

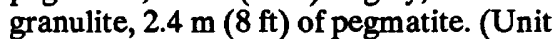
lies across brook at American Optical Company settling pond.) (offset to south

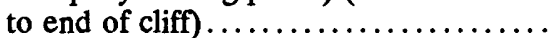

Schistose granulite, fine- to mediumgrained, blue-gray, evenly bedded, containing quartz, feldspar, and biotite; some beds contain many 1 - to $2-\mathrm{mm}$ (0.04- to 0.1 -in-) thick, light-gray layers of quartz-feldspar, some mediumgrained, schistose beds contain graphite; granitic veinlets from $2 \mathrm{~mm}$ (0.1 in) veinlets to $1.5 \mathrm{~m}(5 \mathrm{ft})$ pods of pegmatite; $4 \mathrm{~m}$ $(13 \mathrm{ft})$ of calc-silicate-bearing granulite . Schistose granulite, fine- to mediumgrained, light-gray, granular, fine- to coarse-grained, light- to medium-gray, slightly schistose, containing quartz, feldspar, and biotite, with and without diopside; some beds weather rusty and contain very little biotite; folia of quartz and of quartz-feldspar, 1 to $10 \mathrm{~mm}(0.04$ to 0.4 in) thick, form 5 percent of the rock; lenses as much as 10 by $75 \mathrm{~cm}$ ( 4 by 30 in) are 90 percent quartz and 10 percent feldspar and contain clots of quartzfeldspar, hornblende, and diopside as much as 7.5 by $12.5 \mathrm{~cm}$ ( 3 by $5 \mathrm{in}$ ); $2.4 \mathrm{~m}$ $(8 \mathrm{ft})$ of pegmatite in pods to $1 \mathrm{~m}(3 \mathrm{ft})$ thick; $1.8 \mathrm{~m}(6 \mathrm{ft})$ of calc-silicate-bearing granulite .....................

Schistose granulite, like unit above, $5.6 \mathrm{~m}$ $(18 \mathrm{ft})$; pegmatite, $1.5 \mathrm{~m}(5 \mathrm{ft})$; calcsilicate-bearing granulite, $0.6 \mathrm{~m}(2 \mathrm{ft})$; covered intervals of $3 \mathrm{~m}(10 \mathrm{ft})$ at base and $1.5 \mathrm{~m}(5 \mathrm{ft})$ at top. (Unit lies over

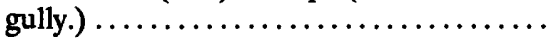

Schistose granulite, some beds with only biotite; biotite chloritized in some beds, and some beds are graphitic (table 1, sample 8); some light-gray bands 1 to 6 $\mathrm{mm}$ ( 0.04 to 0.2 in) thick are crosscutting, pegmatitic quartz and feldspar; calcsilicate-bearing nodules of quartz, feldspar, diopside, and sphene to 10 by $40 \mathrm{~cm}$ (4 by $16 \mathrm{in}$ ) and beds to $10 \mathrm{~cm}$ (4 in) thick; nodules of vitreous quartz to 10 by $38 \mathrm{~cm}$ ( 4 by $15 \mathrm{in}$ ) may be concretions or vein quartz, $3 \mathrm{~m}$ (10 ft) of pegmatite in
Thickness

Meters Feet

4.6 15

35 115

122.2

401

53.3 175 
pods to $1.2 \mathrm{~m}(4 \mathrm{ft}), 3 \mathrm{~m}(10 \mathrm{ft})$ of calc-silicate-bearing granulite. (offset from cliff along river at pipeline crossing)

Covered intervals alternating with many thin bands of pegmatite, gray, schistose granulite, and calc-silicate-bearing granulite; $7.6 \mathrm{~m}(25 \mathrm{ft})$ of gray, schistose granulite,

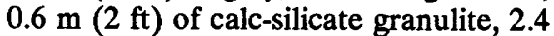

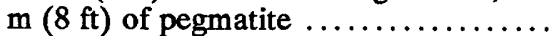
Pegmatite, foliated, in many pods 0.6 to 2.1 m (2 to $7 \mathrm{ft}$ ) thick; some gray, slightly schistose granulite as septae or at base of pegmatites; and covered intervals; $16.8 \mathrm{~m}$

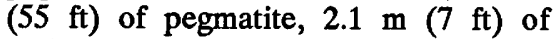
schistose granulite, $14.6 \mathrm{~m} \mathrm{(48} \mathrm{ft)} \mathrm{cov-}$ ered..........................

Covered interval, $1.2 \mathrm{~m}(4 \mathrm{ft})$ of pegmatite near top........................

Schistose granulite, fine- to coarse-grained, medium-gray and gray granulite consisting of quartz, feldspar, and biotite and interlayered thin beds of gray-green quartz-feldspar-diopside calc-silicatebearing granulite; pegmatite pods to 3.7 $\mathrm{m}(12 \mathrm{ft})$ thick; $4.6 \mathrm{~m}(15 \mathrm{ft})$ near middle and $3 \mathrm{~m}(10 \mathrm{ft})$ at top are covered; $5.5 \mathrm{~m}$ $(18 \mathrm{ft})$ of pegmatite, $1.2 \mathrm{~m}(4 \mathrm{ft})$ of calc-silicate-bearing granulite, $7.6 \mathrm{~m}$ (25 $\mathrm{ft})$ covered, $19.5 \mathrm{~m}(64 \mathrm{ft})$ of schistose granulite..$\ldots \ldots \ldots \ldots \ldots \ldots \ldots \ldots$

Schistose granulite, gray granulite; some greenish, chloritized, and calc-silicatebearing in thin beds and nodules to 10 by $30 \mathrm{~cm}$ ( 4 by 12 in); pods of pegmatite to $2.4 \mathrm{~m}(8 \mathrm{ft})$ thick: $3 \mathrm{~m}(10 \mathrm{ft})$ pegmatite,

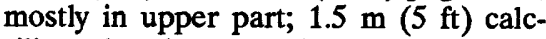
silicate-bearing granulite ............

Covered intervals, five, alternating with four bands of medium-gray, schistose granulite, fine- to coarse-grained, contains quartz, feldspar, biotite, and locally disseminated diopside (table 1, sample 9), and coarse, foliated pegmatite; $5.8 \mathrm{~m} \mathrm{(19}$ $\mathrm{ft}$ ) of gray, schistose granulite, $3.4 \mathrm{~m} \mathrm{(11}$ $\mathrm{ft})$ of pegmatite $\ldots \ldots \ldots \ldots \ldots \ldots \ldots$

Pegmatite, white, feldspar crystals up to 10 $\mathrm{cm}$ (4 in) across; beds and numerous septae to $20 \mathrm{~cm}$ (8 in) thick; gray, schistose granulite and calc-silicate-

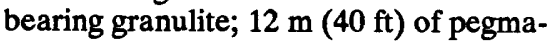

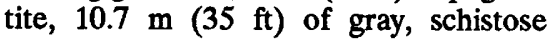
granulite, $1.4 \mathrm{~m}(5 \mathrm{ft})$ calc-silicatebearing granulite.................

Covered. (across Dresser Hill Road and

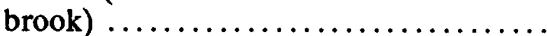

Schistose granulite, medium- to coarsegrained, medium- to light-gray, granular to slightly schistose; feldspar crystals, mostly 5 to $10 \mathrm{~mm}$ ( 0.2 to $0.4 \mathrm{in})$ long, form as much as 10 percent of the rock; abundant stringers of vitreous quartz 1 to $3 \mathrm{~mm}$ ( 0.04 to $0.1 \mathrm{in})$ thick and as much as $45 \mathrm{~cm}$ (18 in) long, and similar stringers of pegmatitic quartz-feldspar granulite commonly 2 to $5 \mathrm{~mm}$ (0.1 to $0.2 \mathrm{in})$

Thickness

Meters

Feet

29

95

32

105

$33.5 \quad 110$

16.5 54

33.8

111

29

95

$105.1 \quad 345$

$24.4 \quad 80$

198.1

650 thick; foliated pegmatite in pods as much as $1.4 \mathrm{~m}(5 \mathrm{ft})$ thick, and covered intervals; $7.9 \mathrm{~m}(26 \mathrm{ft})$ of pegmatite, $19.2 \mathrm{~m}$ $(63 \mathrm{ft})$ of covered interval, $17.1 \mathrm{~m}(56 \mathrm{ft})$ of schistose granulite................

Covered interval; $4.6 \mathrm{~m}(15 \mathrm{ft})$ of pegmatite, septae of gray, schistose granulite near middle; $4.3 \mathrm{~m}(14 \mathrm{ft})$ of pegmatite, $0.3 \mathrm{~m}$ $(1 \mathrm{ft})$ of gray, schistose granulite.......

Schistose granulite; light-gray folia of pegmatitic quartz-feldspar, 2 to $10 \mathrm{~mm}(0.1$ to 0.4 in) thick, form 5 percent of the schistose granulite; 2 percent calcsilicate-bearing granulite in thin beds and pods, contains hornblende adjacent to some pegmatites; pegmatite in pods as

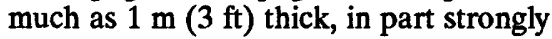
foliated, medium grained, and with ungranulated feldspar crystals to $1.7 \mathrm{~cm}$ (0.67 in) across, and in part foliated, coarse grained, and with ungranulated feldspar crystals to $15 \mathrm{~cm}$ (6 in) across;

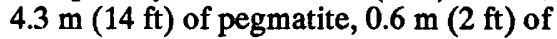
calc-silicate granulite................

Covered intervals, three, alternating with two bands of foliated pegmatite and gray, schistose granulite; $1.8 \mathrm{~m}(6 \mathrm{ft})$ of granulite, $7.3 \mathrm{~m}(24 \mathrm{ft})$ of pegmatite .........

Schistose granulite, fine- to mediumgrained, light-gray, granular, some biotitepoor and quartzose, some containing about 1 percent lavender-pink garnet to 2 $\mathrm{mm}(0.1 \mathrm{in})$ in diameter, garnet concentrated along certain bedding planes; 2.1 $\mathrm{m}(7 \mathrm{ft})$ of pegmatite ................

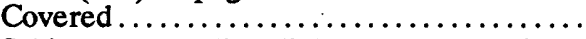

Schistose granulite, light-gray to mediumblue-gray, containing quartz-feldspar and 10 percent biotite; stringers of vitreous quartz 2 to $4 \mathrm{~mm}$ ( 0.1 to 0.2 in) thick and pegmatitic quartz-feldspar 2 to $5 \mathrm{~mm}(0.1$ to 0.2 in) thick; concretions of calcsilicate-bearing rock to 15 by $60 \mathrm{~cm}$ ( 6 by $24 \mathrm{in}$ ) and beds to $10 \mathrm{~cm}$ (4 in) thick; pods of foliated pegmatite to $0.6 \mathrm{~m}(2 \mathrm{ft})$ thick. Feldspar crystals to $10 \mathrm{~mm}(0.4 \mathrm{in})$ make up 5 percent of gray, schistose granulite; a few small garnets around some of these crystals; $4.2 \mathrm{~m}(14 \mathrm{ft})$ of calc-silicate-bearing granulite, $2.1 \mathrm{~m}$ (7 ft) of pegmatite $\ldots \ldots \ldots \ldots \ldots \ldots \ldots \ldots$ Covered interval, with $2.4 \mathrm{~m}(8 \mathrm{ft})$ of gray, schistose granulite in upper half, like that in unit above, but more biotite and with about 3 percent hornblende and a trace of garnet (table 1, sample 3), and with a pod of foliated pegmatite $2.1 \mathrm{~m} \mathrm{(7 \textrm {ft } )}$ thick ...........................

Schistose granulite, medium- to coarsegrained, medium- to light-gray, granular to slightly schistose; feldspar crystals to $10 \mathrm{~mm}$ ( $0.4 \mathrm{in})$ form 5 percent of the schistose granulite; pegmatite pods to 0.6 $\mathrm{m}(2 \mathrm{ft})$ thick make up 5 percent of the rock.........................
Meters

Thickness

44

Feet

4.2

145

18.3

60

22.9

75

45.7

150

$\begin{array}{cr}40 & 131 \\ 4.6 & 15\end{array}$

42.7

140

32

105

15.2

50 
Schistose granulite, similar to unit above, but mostly granular; 10 percent pegmatite in pods to $3.7 \mathrm{~m} \mathrm{(12} \mathrm{ft)} \mathrm{thick,} \mathrm{tour-}$ maline in lower, well-foliated part of one pegmatite and feldspar crystals to $10 \mathrm{~cm}$

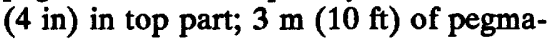

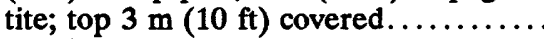

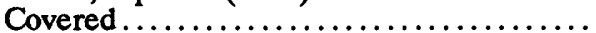

Schistose granulite, medium- to coarsegrained, medium- to light-gray, granular to slightly schistose feldspar crystals to 8

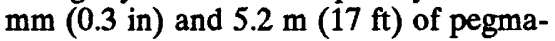

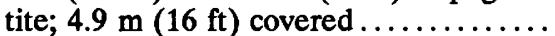

Covered intervals, with two thin bands of

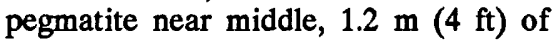
pegmatite ........................

Schistose granulite, fine- to coarse-grained, medium- to light-gray, somewhat schistose; quartz-feldspar-biotite-trace graphite schistose granulite; and fine, lightgray granular quartz-feldspar-biotite schistose granulite; interbeds up to 1.3 $\mathrm{cm}$ (0.5 in) thick of light-gray, quartzose granulite, layers of pegmatitic quartzfeldspar 3 to $8 \mathrm{~mm}$ (0.1 to $0.3 \mathrm{in})$ thick form 5 percent of the rock; pods of pegmatite up to $45 \mathrm{~cm}$ (18 in) thick in top part contain quartz, feldspar, biotite, trace muscovite, 1 percent garnet up to 2 $\mathrm{mm}$ (0.1 in) in diameter, and feldspar crystals up to $6.5 \mathrm{~cm}$ (2.5 in) long; $2.4 \mathrm{~m}$ $(8 \mathrm{ft})$ of pegmatite at top of unit ........

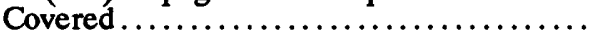

Edge of quadrangle, $110 \mathrm{~m}(350 \mathrm{ft})$ north of Dudley Hill Road

Total ..............................

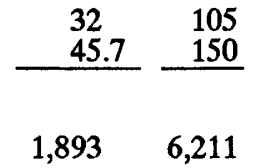

The lower part of the Southbridge Formation is exposed along the northeast side of the Quinebaug River in the Webster Quadrangle. This section extends from the west edge of the quadrangle to the faulted base of the formation southeast of West Dudley where a stream crosses the Penn-Central railroad 1,036 m (3,400 ft) southeast of the bridge on the West Dudley road. The part from the west edge of the quadrangle to $300 \mathrm{~m}(984$ $\mathrm{ft}$ ) west of Blackmere cemetery is very well exposed along the Grand Trunk railroad bed that borders the northeast side of the river. The rest is moderately exposed in scattered outcrops on the slope and hill crest above the river. The lithology is generally uniform and the same as the described upper part, except that the part southeast of Durfee Road is finer grained and transitional into the top of the Dudley Formation. The thickness of the lower part of the section is estimated at approximately $1,800 \mathrm{~m}$ $(5,904 \mathrm{ft})$, but the effects due to displacement by faults crossed are unknown.

\section{Stratigraphic Description of Parts of the Type Section of the Dudley Formation}

The type section of the Dudley Formation is in the Webster Quadrangle, Dudley, Mass., along the northeast side of the Quinebaug River from a pond over a covered branch of the Eastford fault approximately $305 \mathrm{~m} \mathrm{(1,000}$ $\mathrm{ft}$ ) southeast of Mill Road (375,000 ft north; 476,650 ft east, Mass. Coord.) along scattered outcrops across the south end of a hill to an old railroad cut on the northeast side of the Quinebaug River, thence northwest along the railroad bed to a covered fault contact with the Southbridge Formation at a side stream 1,036 m (3,400 ft) southeast of the bridge over the Quinebaug River at West Dudley Road (380,700 ft north; 471,675 ft east, Mass. Coord.). Exposures occur in cuts along the PennCentral (PC) railroad tracks, the adjacent, nevercompleted Grand Trunk (GT) railroad bed, and local roads and in scattered natural outcrops. Given below are descriptions from several representative measured exposures along the type section. Locations are given in relation to the intersection of the Penn-Central railroad and Mill Road. Descriptions are given from top toward base.

\section{Locality 6}

Exposure in cut along GT railroad about $1,875 \mathrm{~m}(6,150 \mathrm{ft}) \mathrm{N} .36^{\circ} \mathrm{W}$. of intersection, near section used for road to gravel pit.

Schistose granulite, fine-grained, mediumgray to brownish-gray, weathers darker, composed of biotite, quartz, and feldspar, thin-bedded and commonly laminated, generally well-bedded. Lower $2.3 \mathrm{~m}$ $(7.5 \mathrm{ft})$ contains small quartz lenses and is less well bedded. Top covered .......

Schistose granulite and granulite, interbedded: Fine-grained, medium-gray to brownish-gray, schistose granulite, composed of biotite, quartz, and feldspar; fine-to medium-grained, light-to mediumgray and greenish-gray granulite, composed of quartz, feldspar, minor biotite, and calc-silicate minerals. Unit weathers slightly darker; thin bedded and commonly laminated; secondary quartz stringers abundant locally. Conformable with unit above. Base covered.............

Total .......................... Thlckness
Meters Feet

Locality 5

Exposure in cut along GT railroad about $1,768 \mathrm{~m}(5,800 \mathrm{ft}) \mathrm{N} .34^{\circ} \mathrm{W}$. of intersection used for road.

Schistose granulite and granulite, interbedThickness Meters Feet ded: Fine-grained, medium-gray to 
Thickness

Meters Feet

brownish-gray, schistose granulite that weathers slightly darker, composed of biotite, quartz, and feldspar; fine- to medium-grained, light- to medium-gray and greenish-gray granulite that weathers slightly darker, composed of quartz, feldspar, minor biotite, and calc-silicate minerals. Unit contains thin beds of granulite locally $1 \mathrm{~cm}$ ( 0.4 in) apart; well bedded. Contacts slightly gradational to sharp. Covered above ................

Schistose granulite and granulite, interbedded. Similar to unit below but with rela. tively more schistose granulite; thin bedded with laminations common. Conformable and gradational above ....

Granulite and schistose granulite, interbedded: Schistose granulite as in unit below; fine-to medium-grained, light-to mediumgray granulite that weathers slightly darker, composed of quartz, feldspar, minor biotite, and some calc-silicate minerals; granulite in thin beds less than $25 \mathrm{~cm}$ (9.8 in) thick interbedded with thin beds and seams of schistose granulite. Conformable and gradational above ....

Schistose granulite, fine-grained, mediumgray to brownish-gray, weathers slightly darker, composed of biotite, quartz, and feldspar, thin-bedded, moderately well bedded; few interbeds of light-gray granulite. Conformable and gradational above. Base covered .................

Total............................

$\frac{4.2}{19.3} \frac{13.5}{63.3}$

\section{Locality 4}

Two natural outcrops in woods northwest of GT railroad bed 1,585$1,676 \mathrm{~m}(5,200-5,500 \mathrm{ft}) \mathrm{N} .29^{\circ} \mathrm{W}$. of intersection.

\begin{tabular}{lc}
\multicolumn{2}{c}{ Thickness } \\
Meters & Feet \\
& \\
5.1 & 16.7 \\
& \\
3.3 & $\frac{10.8}{27.5}$ \\
\hline 8.4 &
\end{tabular}

\section{Locality 3}

Exposure along GT railroad bed $1,021 \mathrm{~m}(3,350 \mathrm{ft}) \mathrm{N}$. $27^{\circ} \mathrm{W}$. of intersection. This is northeast of and above the next-described exposure (locality 2) and may have slight overlap at southeast end. Measured section starts at southeast end of cut where narrow dirt road extends northward from railroad bed. Section is disturbed at southeast end by a few northwest-dipping thrust faults with related adjacent small folds and contorted beds. Movement on thrust faults is west over east.

$\begin{array}{lll}5.0 & 16.4 & \text { Granulite and schistose granulite: Fine- to }\end{array}$ medium-grained, light- to medium-gray and greenish-gray, calc-silicate-bearing granulite composed of quartz, feldspar, minor biotite, and calc-silicate minerals, interbedded with fine-grained, mediumto dark-gray and brownish-gray, schistose granulite composed of biotite, quartz, and feldspar. Unit weathers slightly darker, generally thin bedded and laminated in part, may be in few medium beds. Contacts sharply gradational to gradational. Top covered...............

$4.1 \quad 13.5 \quad$ Granulite and schistose granulite, interbedded: Fine- to medium-grained, light- to slightly darker, composed of quartz, feldspar, minor biotite, and calc-silicate minerals; fine-grained, medium-gray to brownish-gray, schistose granulite that weathers slightly darker, composed of biotite, quartz, and feldspar. Unit contains thin to medium beds up to $50 \mathrm{~cm}$ (19.7 in) that are commonly laminated; well-bedded with slightly gradational to sharp contacts. Conformable with unit

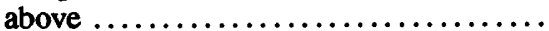

Granulite and schistose granulite, interbedded, similar to second unit below, but beds slightly thicker near base; gradual increase in percentage of schistose granulite toward top, where it forms about two-thirds of unit; well bedded but locally wavy owing to tectonic movement. Conformable with unit above.............. Granulite, fine-grained, light- to mediumgray, weathers slightly darker, composed of quartz, feldspar, minor biotite, and calc-silicate minerals; three beds, 20 to $85 \mathrm{~cm}$ (7.9 to $33.5 \mathrm{in})$ thick, separated by thin beds of fine-grained, medium-gray to brownish-gray, schistose granulite that weathers slightly darker; well bedded, but with slight pinch and swell variations in thickness. Sharp to slightly gradational contacts. Conformable with unit above. .

Granulite and schistose granulite, interbedded, similar to unit below except beds are slightly thicker, some calc-silicatebearing granulite in small pods in addition to beds. Contains some thin, irregular pegmatite lenses. Conformable contact with unit above .............. 3

\section{Thickness}

Meters Feet

21.8

69.9

7

23.0

14

45.9

1.4

4.6 
some thin, irregular pegmatite lenses. Conformable contact with unit above... Granulite and schistose granulite, interbedded, similar to unit below; bedding contorted. A granitic dike, striking northsouth and dipping $35^{\circ} \mathrm{W}$. that separates unit from one above probably intruded along a thrust fault $\ldots \ldots \ldots \ldots \ldots \ldots$.

Granulite and schistose granulite: Fine- to medium-grained, light- to medium-gray and greenish-gray, calc-silicate-bearing granulite that weathers slightly darker and is composed of quartz, feldspar, minor biotite, and calc-silicate minerals, inter-bedded with fine-grained, mediumto dark-gray and brownish-gray, schistose granulite that weathers slightly darker and is composed of biotite, quartz, and feldspar. Unit is thin bedded, $1-10 \mathrm{~cm}$ (0.4-3.9 in), and laminated in part; well bedded where not contorted and sheared. Small, irregular, crosscutting granitic body, possible following a thrust

$2 \quad 6.6$ fault, separates this unit from that above.

Schistose granulite and granulite: Finegrained, medium-gray and brownish-gray to dark-gray, schistose granulite that weathers slightly darker and is composed of biotite, quartz, and feldspar, interbedded with fine-grained, light- to mediumgray, calc-silicate-bearing granulite that weathers slightly darker and contains less biotite than does the schistose granulite. Unit is thin bedded, $1-8 \mathrm{~cm}(0.4-3.1 \mathrm{in})$, and commonly is laminated; well bedded, but wavy to contorted. Northwestdipping thrust fault forms contact with unit above......................

Schistose granulite, fine-grained, mediumgray to brownish-gray, weathers slightly darker, composed of biotite, quartz, and feldspar; thin bedded and laminated at top, but most of unit has shear foliation approximately parallel to bedding; contains few small quartz stringers; pegmatite at exposed base. Two foliated, finegrained granitic dikes $(15 \mathrm{~cm}$ and $20 \mathrm{~cm}$ (5.9 and $7.9 \mathrm{in})$ ) at exposed top of unit to northwest, parallel to small thrust fault, striking N. $20^{\circ} \mathrm{E}$. and dipping $30^{\circ} \mathrm{NW}$., that forms contact with unit above. Base covered $\ldots \ldots \ldots \ldots \ldots \ldots \ldots \ldots \ldots \ldots$

6

Total

\section{Locality 2}

Exposure along PC railroad $1,037 \mathrm{~m}(3,400 \mathrm{ft}) \mathrm{N}$. $30^{\circ} \mathrm{W}$. of intersection.

Schistose granulite, fine-grained, mediumgray to brownish-gray and dark-gray, weathers slightly darker, composed of biotite, quartz, and feldspar; thin bedded, range $1-50 \mathrm{~cm}(0.4-19.7 \mathrm{in})$, mainly $3-15 \mathrm{~cm}$ (1.2-5.9 in), and commonly laminated; few interbeds, less than $5 \mathrm{~cm}$ ( 2 in) thick, of fine- to medium-grained, slightly less granulite with only minor biotite and containing some calc-silicate minerals; generally well bedded, but contains slightly wavy beds that have lineations owing to tectonic movement. Contains minor amount of small quartzfeldspar veinlets and pods............

\section{Locality 1}

Exposure in a cut along the GT railroad $305 \mathrm{~m}$ (980 ft) due north of the intersection of the PC railroad and Mill Road.

Schistose granulite interbedded with calcsilicate-bearing granulite: Fine-grained, medium-gray, brownish-gray, and minor dark-gray, schistose granulite that weathers slightly darker, composed of biotite, quartz, and feldspar; biotite imparts a slightly schistose texture, especially at the top of beds; beds may be slightly graded. Smaller amount of fine- to mediumgrained, light-to medium-gray to greenishgray granulite that weathers slightly darker and is composed of quartz, feldspar, minor biotite, and calc-silicate minerals. Generally thin bedded (1-20 $\mathrm{cm}(0.4-7.9 \mathrm{in}))$, a few beds appear to reach $1 \mathrm{~m}$ (3.28 ft) in thickness, but are probably multiple beds. Contacts generally slightly gradational to sharp. Usually well bedded, but beds may be slightly undulating to locally contorted and variable in thickness owing to tectonic movement. Contains small pods and stringers of quartz and feldspar in places. Section is uniform, with some variation in bed thickness and amount and thickness of calc-silicate-bearing granulite interbeds. Base and top covered 




\section{AVAILABILITY OF BOOKS AND MAPS OF THE U.S. GEOLOGICAL SURVEY}

Instructions on ordering publications of the U.S. Geological Survey, along with prices of the last offerings, are given in the current-year issues of the monthly catalog "New Publications of the U.S. Geological Survey." Prices of available U.S. Geological Survey publications released prior to the current year are listed in the most recent annual "Price and Availability List." Publications that are listed in various U.S. Geological Survey catalogs (see back inside cover) but not listed in the most recent annual "Price and Availability List" are no longer available.

Prices of reports released to the open files are given in the listing "U.S. Geological Survey Open-File Reports," updated monthly, which is for sale in microfiche from the U.S. Geological Survey, Books and Open-File Reports Section, Federal Center, Box 25425, Denver, CO 80225. Reports released through the NTIS may be obtained by writing to the National Technical Information Service, U.S. Department of Commerce, Springfield, VA 22161; please include NTIS report number with inquiry.

Order U.S. Geological Survey publications by mail or over the counter from the offices given below.

\section{BY MAIL}

\section{Books}

Professional Papers, Bulletins, Water-Supply Papers, Techniques of Water-Resources Investigations, Circulars, publications of general interest (such as leaflets, pamphlets, booklets), single copies of Earthquakes \& Volcanoes, Preliminary Determination of Epicenters, and some miscellaneous reports, including some of the foregoing series that have gone out of print at the Superintendent of Documents, are obtainable by mail from

\section{U.S. Geological Survey, Books and Open-File Reports Federal Center, Box 25425 Denver, CO 80225}

Subscriptions to periodicals (Earthquakes \& Volcanoes and Preliminary Determination of Epicenters) can be obtained ONLY from the

\section{Superintendent of Documents \\ Government Printing Omce \\ Washington, D.C. 20402}

(Check or money order must be payable to Superintendent of Documents.)

\section{Maps}

For maps, address mail orders to

\section{U.S. Geological Survey, Map Distribution \\ Federal Center, Box 25286 \\ Denver, CO 80225}

Residents of Alaska may order maps from

\author{
Alaska Distribution Section, U.S. Geological Survey, \\ New Federal Bullding - Box 12 \\ 101 Twelith Ave., Falrbanks, AK 99701
}

\section{OVER THE COUNTER}

\section{Books}

Books of the U.S. Geological Survey are available over the counter at the following Geological Survey Public Inquiries Offices, all of which are authorized agents of the Superintendent of Documents:

- WASHINGTON, D.C.--Main Interior Bldg., 2600 corridor, 18th and C Sts., NW.

- DENVER, Colorado--Federal Bldg., Rm. 169, 1961 Stout St.

- LOS ANGELES, California-Federal Bldg., Rm. 7638, 300 N. Los Angeles St.

- MENLO PARK, California--Bldg. 3 (Stop 533), Rm. 3128, 345 Middlefield Rd.

- RESTON, Virginia--503 National Center, Rm. 1C402, 12201 Sunrise Valley Dr.

- SALT LAKE CITY, Utah-Federal Bldg., Rm. 8105, 125 South State St.

- SAN FRANCISCO, California-_Customhouse, Rm. 504, 555 Battery St.

- SPOKANE, Washington--U.S. Courthouse, Rm. 678, West 920 Riverside Ave.

- ANCHORAGE, Alaska--Rm. 101, 4230 University Dr.

- ANCHORAGE, Alaska--Federal Bldg, Rm. E-146, 701 C St.

Maps

Maps may be purchased over the counter at the U.S. Geological Survey offices where books are sold (all addresses in above list) and at the following Geological Survey offices:

- ROLLA, Missouri--1400 Independence Rd.

- DENVER, Colorado--Map Distribution, Bldg. 810, Federal Center

- FAIRBANKS, Alaska--New Federal Bldg., 101 Twelfth Ave. 


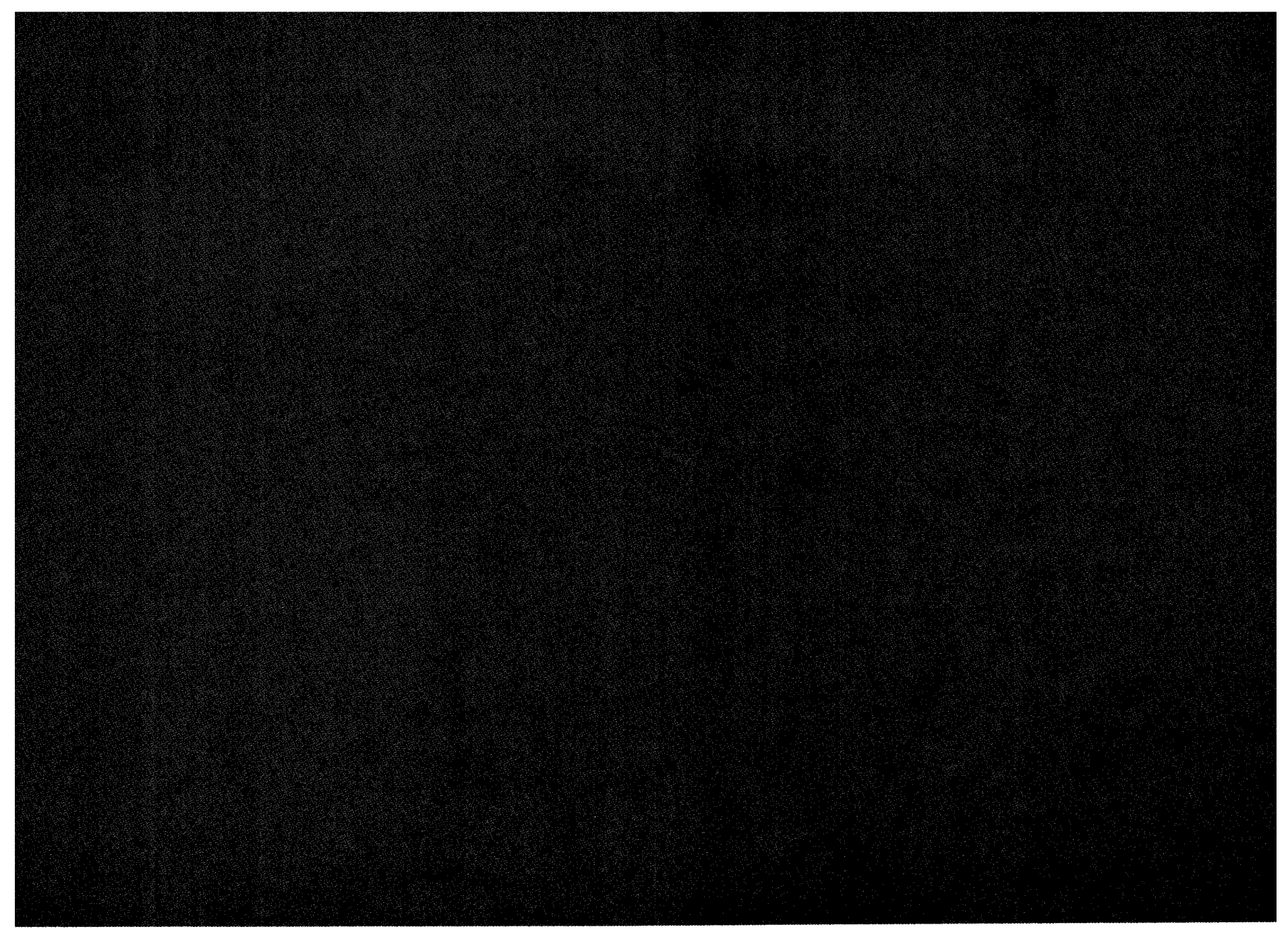

